\title{
Type I Interferons: Distinct Biological Activities and Current Applications for Viral Infection
}

\author{
Shi-fang Lia,b Mei-jiao Gong ${ }^{a, c}$ Fu-rong Zhao ${ }^{a, b} \quad J u n-j u n ~ S h a o^{a, b} \quad$ Yin-li Xie ${ }^{a, b}$ \\ Yong-guang Zhang ${ }^{a, b}$ Hui-yun Chang ${ }^{a, b}$

\begin{abstract}
aState Key Laboratory of Veterinary Etiological Biology, OIE/National Foot-and-Mouth Disease Reference Laboratory, Lanzhou Veterinary Research Institute, Chinese Academy of Agricultural Sciences, Lanzhou, bJiangsu Co-innovation Center for Prevention and Control of Important Animal Infectious Diseases and Zoonoses, Yangzhou, 'College of Veterinary Medicine, Gansu Agricultural University, Lanzhou, China
\end{abstract}

\section{Key Words}

Type I IFN classes $•$ Antiviral $•$ Viral infection $•$ Immunodeficiency virus $•$ Hepatitis $\bullet$ Influenza Virus

\begin{abstract}
The interferons (IFNs) are a primary defense against pathogens because of the strong antiviral activities they induce. IFNs can be classified into three groups: type I, type II and type III, according to their genetic, structural, and functional characteristics and their receptors on the cell surface. The type I IFNs are the largest group and include IFN- $\alpha$, IFN- $\beta$, IFN- $\varepsilon$, IFN- $\omega$, IFN- $\kappa$, IFN- $\delta$, IFN- $\tau$ and IFN- $\zeta$. The use of IFNs for the treatment of viral infectious diseases on their antiviral activity may become an important therapeutic option, for example, IFN- $\alpha$ is well known for the successful treatment of hepatitis $B$ and $C$ virus infections, and interest is increasing in the antiviral efficacy of other novel IFN classes and their potential applications. Therefore, in this review, we summarize the recent progress in the study of the biological activities of all the type I IFN classes and their potential applications in the treatment of infections with immunodeficiency virus, hepatitis viruses, and influenza viruses.
\end{abstract}

\section{Introduction}

Interferons (IFN) were initially described in 1957 as soluble glycoproteins with strong antiviral effects $[1,2]$. Three types of IFNs, types I, II and III, have been classified based on of their genetic, structural, and functional characteristics and their cell-surface receptors [3]. IFN biological activities include antiviral, antiproliferative and immunomodulatory effects in the host response to viral or bacterial infection. As a result, IFN induction is a powerful S.-f. Li and M.-j. Gong contributed equally to this work. 
tool in the host response to cancer or viral infection [2]. Type I IFNs, specifically IFN- $\alpha$ and IFN- $\beta$, are part of the standard treatment for chronic hepatitis B and $C$ virus infections. In addition, interest is increasing in the antiviral efficacy of other novel IFN classes. For example, FeIFN- $\omega$ produced by silkworm larvae is approved in several countries for the treatment of canine parvovirus, feline leukemia virus, and feline immunodeficiency virus infections [4]. IFN- $\varepsilon$ regulates mucosal immunity against viral and bacterial infections, and can suppress HIV replication [5]. Similarly, research has also shown that IFN- $\tau$ is particularly effective in inhibiting HIV infection [6]. Nonetheless, individual antiviral and immunomodulatory properties of type I IFN classes IFN- $\varepsilon$, IFN- $\omega$, IFN- $\kappa$, IFN- $\delta$, IFN- $\tau$ and IFN- $\zeta$ have not been investigated as widely as IFN- $\alpha$ and IFN- $\beta$. In this review, we summarize achievements in defining the distinct biological activities of type I IFN classes as well as their potential clinical use in antiviral therapy.

\section{Biological activities of type I IFNs}

Several classes of type I IFNs exist and they have some similarities. For example, all type I IFNs display the same characteristic structure of helical cytokines with a bundle of four "up-up-down-down" $\alpha$ helices and an additional $\alpha$ helix [7]. In addition, almost all IFN classes are acid stable to $\mathrm{pH} 2$ and are heat-stable. They lack introns and are are closely conserved in length (from 161 to 167 amino acids) and protein sequence (about 75-99\% amino acid sequence similarity) [8-10]. In addition, IFN classes share a common surface receptor of two IFN- $\alpha$ receptor subunits (IFNAR1 and IFNAR2) and have the same mechanism of action of their biological activities [11]. Generally, IFNs induce IFN receptor phosphorylation following binding to IFNAR. Binding leads to activation of the Jak-STAT pathway. Activation gives rise to the activation of ISGs via recognition of upstream sequence elements in promoters and formation of antiviral proteins such as OAS, PKR, ISG and Mx, which exert distinct biological activities (Fig. 1) [2,12-14]. The differences among type I IFN classes is prominent compared to these common points. Detailed lists of main characteristics and biological activities are in Tables 1 and 2, respectively.

\section{$I F N-\alpha / \beta$}

The type I IFN family in humans is composed of 12 IFN- $\alpha$ subtypes encoded by 14 nonallelic genes including one pseudogene and two genes that encode the same protein. One IFN- $\beta$ is encoded by a single IFNB gene in spite of gene duplication $[9$, 54]. The various IFN- $\alpha$ subtypes have many common points. For example, all are clustered on chromosome 9 [55]. IFN$\alpha \mathrm{s}$, which are composed of 165 to 166 aa, have $80 \%$ amino acid sequence identities. IFN- $\beta$ s are composed of

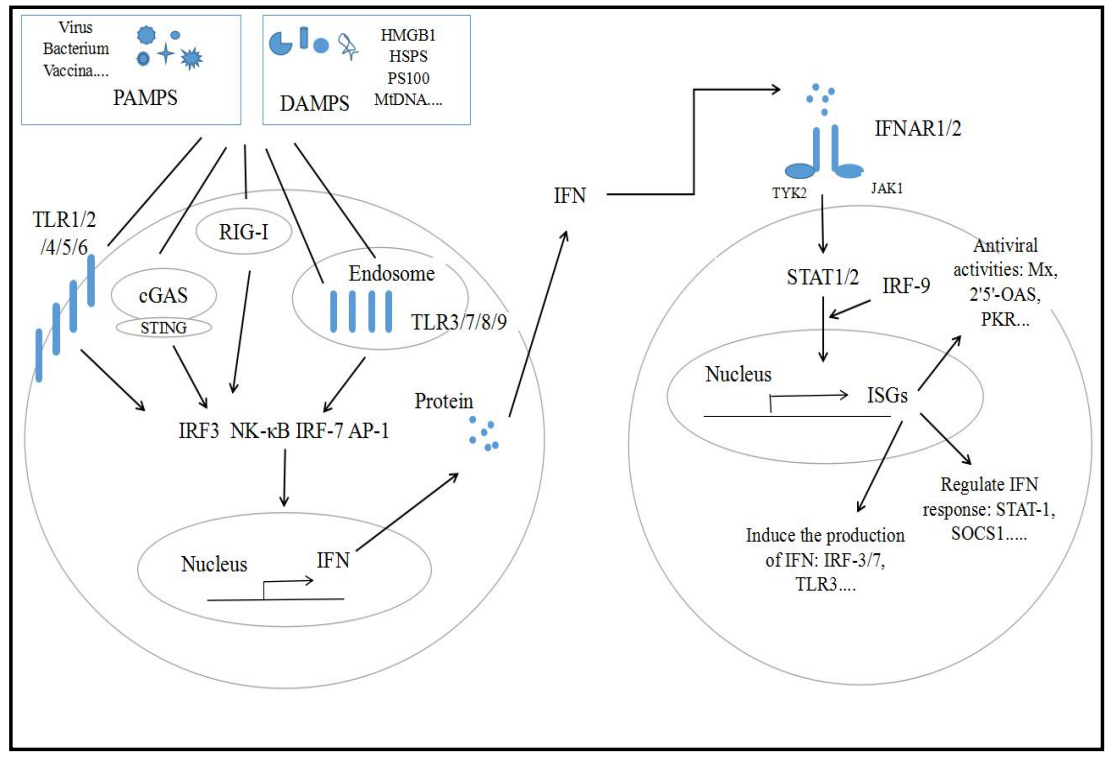

Fig. 1. Type I IFN signaling pathway. 
Table 1. Main characteristics of type I IFN classes

\begin{tabular}{|c|c|c|c|c|c|c|c|c|}
\hline & IFN- $\alpha$ & IFN- $\beta$ & IFN- $\varepsilon$ & IFN- $\omega$ & IFN- $\tau$ & IFN-K & IFN- $\delta$ & limitin \\
\hline species & Most animals & Most animals & $\begin{array}{c}\text { Human, mice, } \\
\text { Swine, } \\
\text { Cattle, } \\
\text { Canine, } \\
\text { Rhesus } \\
\text { macaques, } \\
\text { pangolin, } \\
\text { Fish, } \\
\text { Horse }\end{array}$ & $\begin{array}{c}\text { Human, } \\
\text { Cat, } \\
\text { Pig, } \\
\text { Horse, } \\
\text { Rabbit, } \\
\text { Cattle, Serotine bat, } \\
\text { Sheep }\end{array}$ & Cattle, Sheep & $\begin{array}{l}\text { Human, Horse, } \\
\text { Mouse, Porcine, } \\
\text { Chicken, } \\
\text { Serotine Bat }\end{array}$ & $\begin{array}{l}\text { Pig, } \\
\text { Horse, Sheep }\end{array}$ & Mouse \\
\hline subtypes & $\begin{array}{l}13,6,17,14,9 \\
\text { numbers in } \\
\text { human, horse, } \\
\text { pig, cattle, dog, } \\
\text { respectively }\end{array}$ & $\begin{array}{l}1,4,1 \text { numbers } \\
\text { in human, } \\
\text { horse, pig, } \\
\text { respectively }\end{array}$ & $\begin{array}{c}\text { Only one } \\
\text { number has } \\
\text { been identified } \\
\text { in these species }\end{array}$ & $\begin{array}{c}5,13,7 / 8,12,8,24,5 \\
\text { numbers in human, cat, } \\
\text { pig, horse, rabbit, cattle, } \\
\text { sheep, respectively }\end{array}$ & $\begin{array}{l}3 \text { subtypes in } \\
\text { cattle }\end{array}$ & $\begin{array}{l}\text { one number in } \\
\text { these species }\end{array}$ & $\begin{array}{l}\text { 4,11 numbers } \\
\text { in sheep, pig, } \\
\text { respectively }\end{array}$ & No data \\
\hline $\begin{array}{l}\text { Human } \\
\text { gene } \\
\text { bcus }\end{array}$ & $9 \mathrm{p} 21+3(\mathrm{~T})$ & $9 \mathrm{p} 21+3(\mathrm{~T})$ & $9 \mathrm{p} 21+3(\mathrm{C})$ & $9 \mathrm{p} 21+3(\mathrm{~T})$ & None & None & $9 \mathrm{p} 21+3(\mathrm{~T})$ & None \\
\hline $\begin{array}{l}\text { Main } \\
\text { cellular } \\
\text { source }\end{array}$ & $\begin{array}{c}\text { PDCs, } \\
\text { Hematopoetic } \\
\text { Cells, mainly } \\
\text { leukocytes }\end{array}$ & $\begin{array}{c}\text { DCs, } \\
\text { Fibroblasts and } \\
\text { Epithelial } \\
\text { cell types }\end{array}$ & $\begin{array}{l}\text { Cells of CNS, } \\
\text { female } \\
\text { reproductive } \\
\text { organs }\end{array}$ & $\begin{array}{l}\text { PDCs, Hematopoetic } \\
\text { Cells, mainly leukocytes }\end{array}$ & $\begin{array}{l}\text { Trophoblasts } \\
\text { and } \\
\text { Endometrial } \\
\text { Cells }\end{array}$ & $\begin{array}{l}\text { Epidermal Cells, } \\
\text { Keratinocytes }\end{array}$ & $\begin{array}{l}\text { Blastocyst } \\
\text { Cells }\end{array}$ & $\begin{array}{c}\text { Mature T } \\
\text { Lymphocytes, } \\
\text { Bronchial } \\
\text { Epithelial and } \\
\text { Salivary Duct Cells }\end{array}$ \\
\hline $\begin{array}{l}\text { Receptor } \\
\text { chain } \\
\text { Acid } \\
\text { stability }\end{array}$ & \multicolumn{8}{|c|}{ IFNAR1/IFNAR2 } \\
\hline
\end{tabular}

Table 2. Biological activities of type I IFN classes

\begin{tabular}{|c|c|c|c|c|}
\hline $\begin{array}{l}\text { IFN } \\
\text { classes }\end{array}$ & Induction & Differential biological effects & Induced ISGs & References \\
\hline $\begin{array}{l}\text { Human } \\
\text { IFN }-\alpha\end{array}$ & $\begin{array}{l}\text { By CpG or imiquimod in PBMC; In poly I:C- } \\
\text { stimulated DC and CpG-stimulated } \\
\text { macrophages; By HSV, NDV and RSV in } \\
\text { PBMC }\end{array}$ & $\begin{array}{l}\text { Anti-viral activity against human metapneumovirus, VSV, SFV, influenza A } \\
\text { virus, HBV, HCV, HEV, HIV-1; Induces chemokinesis of T cells and T cell } \\
\text { migration }\end{array}$ & $\begin{array}{l}\text { Potent inducer of IFIT1, } \\
\text { CXCL10, CXCL11, ISG15, } \\
\text { CCL8, 2'5'OAS, } \\
\text { APOBEC3G, APOBEC3A, } \\
\text { PKR and IDO induction }\end{array}$ & {$[15-17]$} \\
\hline $\begin{array}{l}\text { Human } \\
\text { IFN- } \beta\end{array}$ & Most virus & $\begin{array}{l}\text { Anti-viral activity against dengue virus, HSV, HCMV, Ebola virus, HBV, HCV, } \\
\text { influenza A viruses and the SARS-CoV, Zika virus, HIV }\end{array}$ & $\begin{array}{l}\text { Induces PKR, 2'5'OAS, } \\
\text { Mx, ISG }\end{array}$ & {$[18-22]$} \\
\hline IFN- $\varepsilon$ & $\begin{array}{l}\text { Not induced by SIV, pattern recognition } \\
\text { receptor pathways, Semliki Forest virus, } \\
\text { herpes simplex virus } 2 \text { (HSV), mengovirus, } \\
\text { and Chlamydia; Up-regulated by TNF- } \alpha \\
\text { stimulation, seminal plasma, estrogen }\end{array}$ & $\begin{array}{l}\text { Bovine IFN- } \varepsilon \text { has anti-VSV activity against in MDBK, EBK, BT and PK-15 } \\
\text { cells, but not on MDCK and BHK21 cells; rCaIFN- } \text { has high antiviral } \\
\text { activities against VSV, CDV, H1N1 and low in CPV in MDCK cells; Antiviral } \\
\text { activities gainst Vaccinia virus, HIV, HSV2 and C. muridarum infections; } \\
\text { Lower antiviral against vesicular stomatitis virus in aminion-derived WISH } \\
\text { cells }\end{array}$ & $\begin{array}{l}\text { Potent inducer of PKR, } \\
\text { 2'5'OAS }\end{array}$ & {$[4,23-27]$} \\
\hline IFN- $\omega$ & $\begin{array}{l}\text { By PRV or poly(I).poly(C) in PK15 cells; } \\
\text { Not induced by lyssavirus infection }\end{array}$ & $\begin{array}{l}\text { Antiviral activities against CPV, FLV, FIV, BVDV, VSV, FCV, FHV-1, bovine } \\
\text { enterovirus, infectious bovine rhinotracheitis virus, pseudorabies virus, } \\
\text { European bat lyssavirus, influenza virus, HEV, HBV, HCV, HPV }\end{array}$ & $\begin{array}{l}\text { Induces expression of } \\
\text { Mx1, ISG15, ISG56, and } \\
\text { Mx2 }\end{array}$ & {$[3,28-32]$} \\
\hline IFN- $\delta$ & $\begin{array}{l}\text { By PRV in IBRS-2/PK15, PRRSV in Marc- } \\
145 / \text { porcine alveolar macrophages, and } \\
\text { by live SV in the equine PBMC, VSV in } \\
\text { Marc-145/ PK-15; Not induced by } \\
\text { imiquimod-stimulation in pDC }\end{array}$ & $\begin{array}{l}\text { The Porcine IFN- } \delta 8 \text { (PoIFN- } \delta 8 \text { ) showed a significantly stronger activity } \\
\text { than other PoIFN- } \delta 4 \text {, PoIFN- } \delta 5 \text {; Ovine IFN- } \delta \text { has an apparent anti-VSV in } \\
\text { MDBK cells but no on NBL6 cells; Equine IFN- } \delta 1 \text { (EqIFN- } \delta 1 \text { ) and EqIFN- } \delta 2 \\
\text { have an apparent anti-VSV in NBL6 cells, while EqIFN- } \delta 2 \text { has higher } \\
\text { activities in MDBK cells but EqIFN- } \delta 1 \text { not; IFN- } \delta \text { showed effective } \\
\text { protection against PRRSV in porcine AMs but not in MARC-145 cells } \\
\text { Anti-viral activity against HIV and FIV, HPV, BKV, Influenza Virus, }\end{array}$ & $\begin{array}{c}\text { Induces expression of } \\
\text { Mx, OAS }\end{array}$ & {$[33-36]$} \\
\hline IFN- $\tau$ & Not induced in response to dsRNA & $\begin{array}{c}\text { FMDV,VSV, BVDV, Theiler's virus, bovine leukemia virus; Strong antiviral } \\
\text { activity against HIV and FIV than IFN- } \alpha \text {, and be }>30 \text { times less toxic than } \\
\text { human IFN- } \alpha\end{array}$ & $\begin{array}{l}\text { Potent inducer of Mx, } \\
\text { ISG15, and OAS }\end{array}$ & {$[37-45]$} \\
\hline IFN-K & $\begin{array}{l}\text { Downregulated by lyssaviruses; Weak } \\
\text { induced by In poly I:C-stimulated normal } \\
\text { keratinocytes }\end{array}$ & $\begin{array}{c}\text { Anti-HPV activities by inducing Sp100 Proteins; Anti-VSV, EMCV, HCV; } \\
\text { Antiviral activities against avian RNA viruses in ovo; Weak activities } \\
\text { against lyssaviruses }\end{array}$ & $\begin{array}{l}\text { Induces ISG15, ISG56, } \\
\text { MDA5, IRF1, MX1 and } \\
\text { OAS }\end{array}$ & [46-51] \\
\hline limitin & $\begin{array}{l}\text { Not induced by lipopolysaccharide } \\
\text { injection or herpes simplex virus infection }\end{array}$ & $\begin{array}{l}\text { Anti-viral against EMCV, HSV, and MHV; Stronger Antiviral effect than IFN- } \\
\alpha \text {; Same activities in the induction of MHC class I, CTL activity, and anti- } \\
\text { tumor effect to IFN- } \alpha \text {; Lower activities in the inhibition of CFU-GM and } \\
\text { BFU-E colony formation, and myelopoiesis and erythropoiesis in vivo than } \\
\text { IFN- } \alpha\end{array}$ & 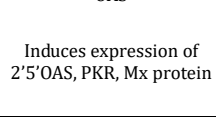 & {$[52,53]$} \\
\hline
\end{tabular}

166 aa and are N-glycosylated. However, in contrast to IFN- $\beta$, only 2 of 13 IFN- $\alpha$ subtypes have glycosylation sites: IFN- $\alpha 2$ and IFN- $\alpha 14$. IFN- $\alpha 2$ is 0 -glycosylated while IFN- $\alpha 14$ is $\mathrm{N}$-glycosylated [56].

Generally, IFN- $\alpha$ is produced by leukocytes while IFN- $\beta$ is a fibroblast product. A limited number of IFNs are produced under healthy conditions [57]. IFN- $\alpha / \beta$ would be considerably upregulated by viral infections or exposure to double-stranded and single-stranded nucleic acids via TLR3 or RIG I, and by some growth factors and cytokines [58]. Many biological activities have been demonstrated such as direct antiviral effects, regulation of immune responses, antiproliferation, and modulation of expression of MHC I and II [11]. However, IFN- $\alpha$ subtypes have distinct biological activities. Differences in receptor-binding affinities among the subtypes are suggested to be responsible for the different activities [59]. For example, IFN- $\alpha 10$ and IFN- $\alpha 17$ have lower bindings affinities to their receptors than IFN- $\alpha 2 \mathrm{a}$ [59]. Distinct receptor affinities can lead to signal differences in the phosphorylation of STAT molecules and mitogen-activated protein [59]. In addition, the quantity of receptors on the surface of specific target cells is associated with different biological activities of IFN subtypes. This finding suggests that abundant IFNAR expression might compensate for the weak 
binding affinity of some IFN- $\alpha$ subtypes [60]. Moreover, the tissue-specific pattern of IFN- $\alpha$ subtypes and receptors may be involved in their biological activities [61]. In some studies, the type of IFN produced and the type of virus used may have influenced the expression and action of different IFN- $\alpha$ subtypes [62]. Some studies found that distinct antiviral activities correlate with virus-specific expression levels of ISG subsets. For instance, some ISGs have strong antiviral effects while others promote viral replication in vitro [63]. This finding indicates that more studies are needed to define their specific biological activities for use in antiviral therapy.

$I F N-\varepsilon$

IFN- $\varepsilon$ was described in 2004 for the first time. It consists of 192 amino acids and shares about $30 \%$ homology with IFN- $\alpha$ and IFN- $\beta$ in humans [8]. Unlike IFN- $\alpha / \beta$, IFN- $\varepsilon$ is constitutively expressed in the lung, brain, skin, small intestine, rectum, jejunum, and reproductive tissues. It shows substantial expression in the uterus, cervix, vagina, and ovarian tissue $[8,24]$.

Studies demonstrate that IFN- $\varepsilon$ is positively modulated by hormones, seminal plasma, and TNF- $\alpha$ stimulation and expression correlates negatively with progesterone levels $[8,64,65]$. Two stable stem-loop structures (loops 1 and 2) were identified in the $5^{\prime}$-untranslated region of IFN- $\varepsilon$ mRNA, and they markedly suppresses IFN- $\varepsilon$ mRNA expression. However, only loop 1 is essential for enhancing mRNA expression unless the loop structure is disrupted [66]. The molecular transporter and chaperone Importin9, which binds to the IFN- $\varepsilon$ 5'-untranslated region (UTR) stem-loop structures, affects IFN- $\varepsilon$ constitutive expression. Expression levels of IFN- $\varepsilon$ decrease following IP09 overexpression and increase in response to IP09 silencing [66]. These findings suggest that the IP09, with the participation of stem-loop structure 1 , serves as a negative, specific, post-transcriptional modulator of IFN- $\varepsilon$ mRNA.

It has been demonstrated that IFN- $\varepsilon$ also exerts its biological activity by stimulating immune mediators and activating the JAK-STAT signal pathways in vitro and in vivo [8]. For example, a recombinant vaccinia virus co-expressing HIV gag or pol genes and murine IFN- $\varepsilon$ (VV-HIV-IFN- $\varepsilon$ ) inhibits growth of VV in L929 murine cell lines and increases upregulation of activation markers (CD69 and CD86) and antiviral protein expression [26]. Between IFNAR1 and IFNAR2, IFN- $\varepsilon$ has a higher binding affinity for IFNAR1 [67]. In addition, unlike IFN- $\alpha$, IFN- $\beta$ is not induced in response to activation of TLRs $2,3,4,7 / 8$, and 9 [64]. Other differences exist between IFN- $\varepsilon$ and other IFNs. First, the antiviral, natural killer cell-cytotoxicity activity and antiproliferative activities of IFN- $\varepsilon$ are weaker than IFN- $\alpha$ and IFN- $\beta$ [27]. Second, some studies showed that IFN- $\varepsilon$ exhibits antiviral activity against cells derived from species that have near relatives and are expected to be homologous cells $[23,25]$. Third, IFN- $\varepsilon$ differs from IFN- $\alpha$ in macrophages by inducing an antiviral state mediated by more different factors [4]. Studies have revealed that numbers of genes or expression levels induced by type I IFN, IL-6, and TNF pathways in response to IFN- $\alpha$ and IFN- $\varepsilon$ are not identical, in spite of some overlap among IL- $1 \alpha$, IL-1RA, IL-4, VEFG, and GCSF [4]. IFN- $\alpha$ mediates more genes and upregulates genes more than [The phrasing of this edit should be checked for accuracy.]IFN- $\varepsilon$ in the type I IFN signaling pathway, whereas IFN- $\varepsilon$ induces more genes in the TNF- $\alpha$ pathway and more ROS generation and phagocyte activation than IFN- $\alpha$, to block HIV replication [4].

$I F N-\omega$

Since the discovery of IFN- $\omega$ genes in humans about 30 years ago, IFN- $\omega$ has been identified in other animal groups including feline, porcine, equine, rabbit, cattle, and serotine bat, but not noted in canines or mice [3]. Treatment with IFN- $\omega$ is suggested to be effective for patients who are resistant to IFN- $\alpha$ because the antigenic structure of IFN- $\omega$ is distantly related to IFN- $\alpha, \beta, \lambda$, with no crossreaction with antibodies against these other IFNs [68]. Recombinant FeIFN- $\omega$ is approved for treatment of FLV and FIV infections in some countries. FIFN- $\omega$ has 13 subtypes that have high similarity (95\% to 99\%) at the nucleic acid and amino acid level. All of them contain an N-terminal secretory signal sequence at position 1 to 23 . Lengths of mature FeIFN- $\omega$ subtype polypeptides are 173 aa (except FeIFN- $\omega 2$ and FeIFN- $\omega 4$ 
which have 180 aa). The mature amino acid sequence of FeIFN- $\omega$ has six additional amino acids at the carboxyl-end and an N-glycosylation recognition site that differs from other mammalian subtypes [69]. In addition, seven prolines are conserved among these subtypes, four at positions 4, 26, 39, and 117 of mature proteins, similar to other mammalian IFN- $\omega$ proteins at positions $4,26,39$, and 116 , respectively $[69,70]$. The cysteines at positions 1 , 29,100 , and 140 of the mature proteins correspond to IFN- $\omega$ at positions $1,29,99$, and 139.

IFN- $\omega$ has antiviral activities similar to other types I IFNs. However, unlike IFN- $\alpha$, it has cross-species activity to some extent. This activity indicates that cells have a tendency to be insensitive to IFN- $\omega$ from distantly related species [23]. IFN- $\omega$ is involved in the nonspecific response based on increased expression of several acute phase proteins and MHC I molecules; upregulation of the phagocytic activities of whole blood cells, macrophages and NK cell activities; and decreased concurrent viral excretion [71-74]. Different therapy protocols might also contribute to the distinct expression of innate immunity cytokines following IFN- $\omega$ treatment. For example, IL-6 plasma levels decrease and proviral load increase in FIV-cats treated with rFeIFN- $\omega$ by a subcutaneous licensed protocol. IL-6 mRNA expression decreases in an oral group. Viremia and other cytokines (IL-1, IL-4, IL-10, IL-12p40, IFN- $\gamma$ and TNF- $\alpha$ ) do not change with therapy [75]. A previous study showed that cytotoxic effects (e.g. apoptosis, necrosis, and early senescence) of human IFN $\beta$ gene lipofection showed the same or a superior effect to that of high doses of the exogenously applied recombinant IFN $\beta$ protein [76]. Based on these findings, the researchers also found that fIFN- $\omega$ lipofection and expression is equal to or more effective than rFIFN- $\omega$ protein at suppressing cell growth by inducing ROS generation, mitochondrial potential disruption and calcium uptake [77]. These kinds of approaches may offer equal or superior biological activities with less adverse effects for the treatment of some diseases.

\section{IFN- $\kappa$}

Similar to IFN- $\varepsilon$, which is constitutively expressed in specific tissues, IFN- $\kappa$ is also mainly expressed in the uterus [78]. It is also detected in other tissues such as the Peyer's patch, ovary, liver, and peritoneal macrophages although at low levels. It is not detected in brain, kidney, spleen, tonsil, heart, small intestine, colon, placenta, or testis $[51,78]$. The IFN- $\kappa$ gene has classic characteristics including a 5'-UTR, 3'-UTR, and open reading frame. The gene contains two exons (although it is intronless in the serotine bat), separated by an intron. The second exon cannot be translated into an amino acid sequence [78]. Bovine IFN- $\kappa$ does not have an $\mathrm{N}$-linked glycosylation site but contains four $\mathrm{O}$-linked glycosylation sites and a signal peptide of 27 amino acids, which is longer than other type I IFNs such as IFN- $\alpha$, IFN- $\beta$, IFN- $\varepsilon$, or IFN- $\omega$. Both human IFN- $\kappa$ and BoIFN- $\kappa$ contain three putative VRE elements at the same position. Studies found that the length of the CD loop region is responsible for the structural differences between IFN- $\kappa$ and other type I IFNs [51]. For example, BoIFN- $\kappa$ has an insertion of 20 amino acids while human IFN- $\kappa$ contains only 13 amino acids.

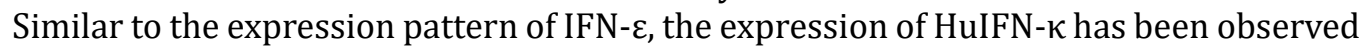
only in keratinocytes and certain lymphoid cell populations. such as monocytes, and monocyte-derived dendritic cells [79]. HuIFN- $\kappa$ has demonstrated antiviral activity against VSV and EMCV [79]. Habiger and others revealed that IFN- $\kappa$ reduces human papillomavirus transcription and replication in CIN612-9E cells by inducing Sp100 proteins, which are restriction factors for HPV18 infection [50]. However, these biological activities of IFN- $\kappa$ are lower than IFN- $\alpha / \omega$. In a study, BoIFN- $\kappa$ had a protective effect against VSV or BVDV infection of MDBK and BT cells even though the effects were less than the effects of BoIFN- $\alpha A$ [51]. In another study [48], recombinant esIFN- $\kappa$ suppressed EBLV-1, EBLV-2, and RABV replication in an Eptesicus serotinus brain cell line. However, the effect was weaker than esIFN- $\omega$. The authors suggested that IFN- $\kappa$ may be important for antiviral activity by inducing production of IFN- $\beta$ in reproductive organs such as the uterus and ovary as well as being a possible skin defense against cellular challenges and skin-infecting pathogens $[47,79]$. 


\section{$I F N-\delta$}

IFN- $\delta$ was identified by Lefevre and Boulay in 1993 [6]. It is expressed in porcine blastocysts during implantation, suggesting unique functions during pregnancy [6]. IFN- $\delta$ seems more closely related to the IFN- $\alpha$, IFN- $\tau$, and IFN- $\omega$ cluster than to IFN- $\beta$. Of note, the IFN- $\delta$ family comprises a large number of members with diversity that is greater than other multigene porcine or horse IFN families such as IFN- $\alpha$ and IFN- $\omega$ [36]. In the porcine family, 11 PoIFN- $\delta$-related genes and 7 pseudogenes have been identified within a 600 $\mathrm{kb}$ region on porcine chromosome 1 [36]. The number of cysteines in porcine IFN- $\delta$ has no equivalent among other type I IFNs: the preprotein contains 9 and the mature protein 7 Cys residues. Five of the seven cysteine residues of the mature protein (positions 9, 56. 58,107 and 145) are atypical among type I IFNs. Mature Porcine IFN- $\delta$, with 149 residues, possesses the shortest sequence of all known type I IFNs, while ovine IFN- $\delta$ (139 aa) appears to be the smallest known natural mammalian type I IFN $[33,34]$. Some IFN- $\delta$ s are probably highly glycosylated, as they display one or two potential N-glycosylation sites in OvIFN- $\delta$ and the porcine IFN. All IFN- $\delta$ s have two other cysteine residues, Cys77 and Cys128, except for IFN- $\delta 2$ and IFN- $\delta 7$, which have an additional $\mathrm{COOH}$-terminal cysteine residue, Cys166.

IFN- $\delta$ s exhibit antiviral and immunomodulatory activity through typical type I IFN signaling, with lower antiviral activities than IFN- $\alpha$ [35]. However, the differential affinity of IFN- $\delta$ for certain hosts could influence their biological activities. For example, an OvIFN- $\delta$ supernatant has apparent antiviral activity with MDBK cells but no antiviral activity is detected with NBL6 cells. EqIFN- $\delta 1$ and EqIFN- $\delta 2$ supernatants have an apparent titer with the NBL6 cell line, but the EqIFN- $\delta 1$ gene product has a very narrow species specificity compared to EqIFN- $\delta 2$ [34]. In addition, this activity is distinct among cell subtypes, in challenges with different viral species. For example, PoIFN- $\delta 8$ showed a significantly stronger activity against PRV in IBRS-1/PK-15 cells than PoIFN- $\delta 4$, PoIFN- $\delta 5$ [36]. However, in another study, IFN- $\delta 8$ showed the lowest activity of among PolFN- $\delta$ s in a high anti-VSVactivity group with MARC-145 cells [35].

\section{IFN- $\tau$}

IFN- $\tau$ was first discovered as an antiluteolytic protein during ovine pregnancy. It is constitutively secreted by trophoblasts and endometrial cells beginning on about day 10 , increasing between days 13 and 16, when it reaches a peak, with secretion stopping after day 21 of pregnancy. IFN- $\tau$ is pivotal for maintaining levels of progesterone from the corpus luteum during the initial stages of postconception [80]. IFN- $\tau$ shares about $75 \%$ identity with IFN- $\omega$ and has 172 aa with two disulfide bridges (1-99, 29-139) and an amino terminal proline. Not every IFN- $\tau$ is glycosylated. For instance, ovine IFN- $\tau$ lacks glycosylation, while bovine IFN- $\tau$ is N-glycosylated at ASN78 and caprine IFN- $\tau$ is a mixture of nonglycosylated and glycosylated forms. Although secretion is specific to ruminant mammals (e.g., sheep, cows, oxen, goats, gazelle, giraffe and deer), all have several variants of IFN- $\tau$, except for giraffes, and 7 putative analogs of IFN- $\tau$ are identified in humans [80-83]. Studies show that human trophoblast IFN in placental trophoblast cells has $85 \%$ sequence identity to IFN- $\tau$ in ruminants [79].

Similar to IFN- $\alpha$ and IFN- $\beta$, IFN- $\tau$ possesses antiviral activity and antiproliferative effects. IFN- $\tau$ has a receptor binding domain at the C-terminus and a biologically active site at the $\mathrm{N}$-terminus [84]. IFN- $\tau$ is suggested to have comparable antiviral activity effects as IFN- $\alpha$ from the same species. It has high species specificity and some biological activities are remarkably decreased when administered to another species [85, 86]. IFN- $\tau$ also stimulates some interleukin expression and secretion such as IL-6 and IL-8. However, the mechanism involved in inducing cytokine secretion is dependent on STAT3 rather than STAT1 signaling [87]. IFN- $\tau$ displays $>30$ times less toxicity than IFN- $\alpha$ [45, 88]. This difference in cytotoxicity is illustrated by the differential selectivity of individual $\mathrm{N}$-termini towards receptors and the differential degree of receptor avidity [84]. Overall, these unique properties will be useful in the treatment of viral diseases, including HIV infection and hepatitis. 
$I F N-\zeta$

Based on growth inhibition of a myelomonocytic leukemia cell line, IFN- $\zeta$ was initially cloned in 2000 [89]. A seemingly secreted glycoprotein, IFN- $\zeta$ is composed of 182 aa residues with a signal peptide of 21 amino acids at the $\mathrm{N}$-terminal end and an $\mathrm{N}$-linked glycosylation site at amino acid residue 68. IFN- $\zeta$ lacks an internal transmembrane domain. It appears to have an IFN-like globular structure of five long $\alpha$-helices and one short helix in the middle of a loop connecting helices $B$ and $C$, with possible disulfide bonds between residues 52 and 157 and between residues 80 and 130 [90]. IFN- $\zeta$ shares high nucleotide homology with IFN- $\alpha$ and IFN- $\beta$ at residues 45-60, 105-115, and 135-165, corresponding to the N-terminal half of the AB loop, the $C$ helix, and the DE loop, together with helices D and E [90].

IFN- $\zeta$ shares activities with other type I IFNs such as IFN- $\alpha$ : It induces the surface expression of MHC class I, enhances CTL activities, and inhibits growth of lymphohematopoietic cell lines as strongly as IFN- $\alpha$. This kind of IFN has relatively higher antiviral activity than IFN- $\alpha$ [52]. Apart from their antiviral effects, other differences exist among them: (I) Signals induced by IFN- $\zeta$ are similar but distinct in contrasted to signals of other type I IFNs. Studies revealed that IFN regulatory factor-1 (IRF-1) dependency for antiviral activities is distinct between IFN- $\zeta$ and IFN- $\alpha$. A higher concentration of IFN- $\zeta$ is needed compared to IFN- $\alpha$ for antiviral activity and transcription of proteins in IRF-1deficient fibroblasts [53] (II) Some common adverse effects such as myelosuppression and fever are not observed in mice treated with IFN- $\zeta$ compared to IFN- $\alpha$ [52] (III) IFN- $\zeta$ does not inhibit colony production of myeloid and erythroid progenitors while IFN- $\alpha$ is known to suppress lymphohematopoiesis [52]. In addition, IFN- $\zeta$ suppresses the proliferation of megakaryocyte progenitors without influencing megakaryocyte differentiation, although higher concentrations are required. A possible explanation is that IFN- $\zeta$ induces lower expression of Daxx and weaker phosphorylation of Tyk2 and Crk than IFN- $\alpha$ [91] (IV) Formation of IFN- $\zeta$ is distinct from other known IFNs. IFN- $\zeta$ is constitutively produced by mature $\mathrm{T}$ lymphocytes in the spleen and thymus and by bronchial epithelial and salivary

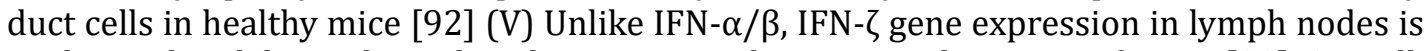
unchanged with lipopolysaccharide injection or herpes simplex virus infection [92]. Overall, the narrow biological activities of limitin may indicate that it is important in homeostasis of lymphoid organs and their response to pathogens.

\section{Current potential applications of type I IFN classes}

\section{Immunodeficiency virus}

IFN- $\alpha$ and HIV in humans. Some clinical trials on HIV infection show that treatment with IFN- $\alpha$ has significant therapeutic potential, alone or in combination with long-term ART. It has been demonstrated that IFN- $\alpha$ is well tolerated and decreases HIV viral loads and proviral DNA levels in CD4 $4^{+} \mathrm{T}$ cells, induces tumor regression and suppresses HIV p24 core antigen levels [93-96]. Distinct anti-HIV effects of IFN- $\alpha$ subtypes are seen. For example, although IFN- $\alpha 2$ has been used in human clinical trials for HIV-1 patients, it as less potent anti-viral activity than IFN- $\alpha 14$ when used in postexposure prophylaxis or treatment of acute viral infection, with better regulation of immune hyperactivation [97]. In addition, IFN- $\alpha 14$ therapy correlates with increasing patterns of host innate immunity, including significantly higher induction of tetherin and MX2, increasing APOBEC3G signature mutations in HIV-1 proviral DNA, and higher frequencies of TRAIL+NK cells. Unlike other antiretroviral drugs, IFN- $\alpha 14$ decreases both viremia and proviral loads [97]. However, HIV seems to become resistant to IFN- $\alpha$ following infection, especially in chronic viral infections with $\mathrm{CD}^{+}{ }^{+} \mathrm{T}$-cell depletion and inhibition of memory B-cell reconstitution, involving evasion mechanisms to avoid antiviral responses to IFN- $\alpha$ during IFN- $\alpha$ therapy $[98,99]$. Clinical trials of chronically infected patients found that IFN- $\alpha$ therapy fails to suppress HIV-1 replication and causes severe side-effects, including toxicity, ART failure and progression to AIDS [100]. Some novel methods and therapeutic strategies that can overcome viral latency have been developed 
such as HDAC, disulfiram, galectin-9, ingenol-3-angelate, prostratin, 5-azadC, bryostatin-1, and Runx1 $[100,101]$. TLR7/8 agonists induce production of IFN- $\alpha$ that effectively inhibits HIV-1 replication in activated lymphocytes, macrophages or latently infected monocytic cell lines [102, 103]. Because HIV eradication is not achieved by highly active antiretroviral therapy, a strong rationale to investigate the curative potential of IFN- $\alpha$ is needed. Recently, IFN- $\lambda$, a type III IFN, was identified and shown to have similar biological characteristics as IFN- $\alpha$ and IFN- $\beta[104,105]$. However, it has a more restricted receptor complex and restricted tissue expression than IFN- $\alpha$, and these features makes it an ideal therapeutic antiviral agent against HCV [106]. Preclinical studies showed that treatment with IFN- $\lambda$ effectively inhibited HCV replication in human hepatocytes $[107,108]$. Furthermore, it reduced the incidence of IFN- $\alpha$-induced adverse events, and the IFN- $\lambda$-based treatment showed no significant hematological toxicity. Therefore, the application of IFN- $\lambda$ in the treatment of chronic hepatitis C warrants investigation.

$I F N-\varepsilon$ and HIV in humans. Previous studies suggest that the upregulated expression of IFN $\varepsilon$ in the cervical epithelium is associated with decreased levels of genes related to HIV-1 DNA integration and replication. In addition, susceptibility to HIV infection has a negative relationship with IFN $\varepsilon$ levels during the menstrual cycle [109-111]. These results indicate that the IFN $\varepsilon$ cytokine may contribute to anti-HIV responses. Several studies demonstrated that human IFN- $\varepsilon$ suppresses HIV replication at stage(s). One study [4] found that IFN- $\varepsilon$ blocks HIV infection in the early stages of the HIV cycle, from viral entry to nuclear import, by inducing CC-chemokines, downregulating CCR5, and inhibiting reverse transcription and nuclear import. While this activity reached a high point after 24 hours of treatment and then decreased, a potential mechanism is that IFN- $\varepsilon$ induces significant phagocytosis and ROS, which contribute to blocking HIV replication. However, protection does not appear to operate through known type I IFN-induced HIV host restriction factors such as APOBEC3A and SAMHD1. In a study conducted by Garcia-Minambres et al. [112], IFN- $\varepsilon$ mediated its antiviral activity at different steps of the HIV replication cycle by inducing expression of HIV restriction factors including TRIM5 $\alpha$, MX2, HERC5, BST2, IFITM3, and APOBEC3G. The levels induced were comparable to IFN- $\alpha$ and IFN- $\beta$. In addition, IFN- $\varepsilon$ also decreased the infectivity of progeny virion particles at that stage of infection by upregulating expression of HIV restriction factors such as IFITM3. Future studies are needed to learn the exact mechanism of IFN- $\varepsilon$-mediated HIV inhibition, to develop safer new strategies to prevent HIV transmission.

IFN- $\tau$ and HIV in humans. IFN- $\tau$ has more potency than human IFN- $\alpha 2 \mathrm{a}$ in suppressing HIV replication in monocyte-derived macrophages, which are a reservoir of HIV during the early stages of infection, in spite of its lower affinity for IFNAR [113]. Several potential mechanisms are involved in this action. (I) IFN- $\tau$ upregulates expression of cellular antiviral

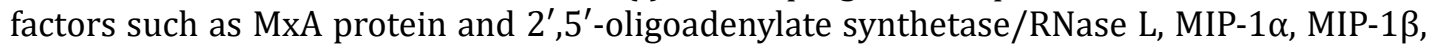
RANTES, IL-4, IL-10, and IL-6, but not IL-1ß or TNF- $\alpha$. These effectors further contribute to degrading integration of intracellular viral RNA. In particular, $\beta$-chemokines suppress HIV replication by competitively binding to CCR5 a co-receptor for HIV [91, 113-115]. (II) It suppresses reverse transcription by preventing formation of the reverse transcription complex [114]. IFN- $\tau$ seems to have the highest antiviral activity when administered orally, and it shows no evidence of toxicity compared to IFN- $\alpha 2$ even at concentrations of $1000 \mathrm{U} /$ $\mathrm{mL}[43,45]$. Overall, efficiently preventing HIV infection and production of viral particles may be an alternative HIV treatment to IFN- $\alpha$. However, some studies indicate that IL- 6 may promote viral replication at later stages of infection. Nonetheless, IFN- $\tau$ resulted in greater decreased viral RNA than direct treatment with IL-6 [113]. Some conflicting results about whether IFN- $\tau$ elicits production of IFN- $\gamma$ associated with a predominately Th1 response have been reported $[116,117]$. Thus, additional research is needed to investigate the exact functions of these cytokines in the mechanism of IFN- $\tau$ antiviral effects. 
IFN- $\omega,-\zeta$ and FIV in cats. rFeIFN- $\omega$ was the first licensed interferon compound for use in cats for treatment of FIV and FeLV infection [118]. The first study supporting its clinical application was conducted in 2004 and found that cats infected with FeLV or co-infected FIV displayed a significant clinical improvement and a prolonged survival with rFeIFN- $\omega$ treatment $[73,116]$. Other studies showed that treatment with rFeIFN- $\omega$ improved clinical signs, decreased concurrent viral excretion and hematologic parameters, and increased levels of acute phase proteins, a key component of the innate immune system $[71,119]$. However, rFeIFN- $\omega$ did not change hypergammaglobulinemia, proviral load, or viremia. These results suggest that a main innate immune reaction rather than acquired immunity is induced by rFeIFN- $\omega[72,119]$. rFeIFN- $\omega$ therapy seems to be cost-limiting so an alternative oral protocol for FIV-infected cats has been suggested. Similar to the licensed protocol, clinical improvement was observed in cats treated with oral rFeIFN- $\omega$ [72]. However, hematology, biochemistry profiles and APP profiles did not significantly change in cats following this protocol [72]. Other studies showed that an rFeIFN- $\omega$ licensed protocol decreases concurrent viral infections, even if no true changes are observed in FIV viral load. However, a significant clinical improvement in cats treated with oral rFeIFN- $\omega$ was observed, although no changes were seen for viral load or concurrent viral infection [120]. These results indicate that the two protocols are probably acting distinctly. Th- 1 and Th-2 responses do not significantly change with either protocol, and only levels of IL-6, a pro-inflammatory cytokine involved in different immune pathways, particularly the innate immune response, significantly change in both groups [75]. In cats treated with the licensed protocol, IL-6 plasma levels are significantly reduced. Treatment with oral rFeIFN- $\omega$ did not change IL- 6 plasma levels, but concurrent mRNA expression significantly decreased [75]. These results indicate that rFeIFN- $\omega$ has anti-inflammatory properties and higher pulsate therapy is more available than continuous low dose therapy for decreasing pro-inflammatory stimuli [75].

Strong immunomodulatory, antitumor, and antiviral effects with weak myelosuppressive and low acute toxic effects of limitin indicate that it is superior than IFN- $\alpha$ [53]. It is demonstrated to have antiviral activities against mouse hepatitis virus. Therefore, a human homolog of limitin or an engineered cytokine with some features of limitin may be useful for treatment of diseases such as HBV or HCV infection. High-dose and/or long-duration limitin therapy could improve viral status [52].

\section{Hepatitis}

IFN and viral hepatitis $B$ \& C in humans. The combination of pegylated IFN- $\alpha$ plus ribavirin (PegIFN $\alpha-R B V$ ), including PegIFN $\alpha-2 b$, and PegIFN $\alpha-2 a$, is not only a treatment option for HBV and HCV but is still the standard treatment for these infection in most countries because the new DAAs are not yet approved, too expensive, or not subsidized. Interestingly, PegIFN $\alpha$-RBV has acquired the maximum quality-adjusted life-years compared to other antiviral treatments in our country [121]. PegIFN $\alpha-2 b$ and PegIFN $\alpha-2 a$ have similar clinical efficacy for HCV therapy although they have different pharmacokinetic properties [122]. Similar to responses to other viruses, IFN- $\alpha$ subtypes have different anti-hepatitis virus activities. IFN- $\alpha 2 \mathrm{a}$ and IFN- $\alpha 2 \mathrm{~b}$ are superior to IFN- $\alpha 1$, IFN- $\alpha 16$ and IFN- $\alpha 21$ against HCV replication [123]. However, studies show that IFN- $\alpha 8$ is the most effective at suppressing intracellular HCV replication among human IFN- $\alpha 1, \alpha 2, \alpha 5, \alpha 8, \alpha 10$, and IFN- $\alpha$ con1 [124]. IFN- $\alpha 17$ has three times more anti-HCV activity than IFN- $\alpha 2$ a against HCV in Huh7 cells. These different efficiencies may be caused by different affinities for IFNAR2, and as a result, different stimulation of the Jak-Stat pathway [125]. Although the use of PegIFN- $\alpha$ to replace non-PegIFN- $\alpha$ significantly increased therapy efficacy, it was not tolerated or safe. Studies found that the absence of KIR2DS2 is associated with a larger and faster decline in platelet count during HCV treatment with PegIFN- $\alpha$ [126]. A weak response rate to high doses and long durations of IFN $\alpha-2 b$ therapy was observed in patients coinfected with HBV [127]. For these reasons, new, more effective therapies for hepatitis virus patients are awaited. 
Since the discovery of the antiviral activities of IFN- $\omega$ against HEV, recombinant human IFN- $\omega$ has been shown to be well tolerated in humans. It induces a SVR in patients infected with hepatitis $C$ virus genotypes 1,2 and 3 in clinical trials [128]. IFN- $\omega$ considerably reduces the production of $\mathrm{HBsAg}$, comparable to the reduction obtained by treatment with IFN- $\alpha$ [29]. In a series of safety pharmacology experiments or in local tolerance studies, IFN- $\omega$ did not correlate with any biologically relevant adverse effects including acute, subacute, subchronic and reproductive toxicity in monkeys, rabbits, and rats [30]. Several strategies are suggested to improve IFN- $\omega$ effects. Nonglycosylated recombinant IFN- $\omega$ has similar antiviral potency to IFN- $\alpha$, while glycosylated recombinant IFN- $\omega$ is more potent in decreasing HCV RNA replicons than either IFN- $\alpha$ or non-glycosylated IFN- $\omega$ [129]. Eight additional TFs that are not induced by IFN- $\alpha$ are activated by glycosylated IFN- $\omega$ and may contribute to its high potency. These TFs are sterol regulatory element binding transcription factor, activating enhancer binding protein 2-like YY1 site, interferon conserved sequencebinding protein, erythroid Kruppel-like factor gene, homeotic gene forkhead of Drosophila 8/hepatocyte nuclear factor 3 /mouse forkhead lung protein, HNF-1A, interferon consensus sequence binding protein, and lymphocyte-enriched DNA binding protein LyF [129]. When expressed in yeast, recombinant human IFN- $\omega$-Fc fusion protein (rhIFN- $\omega$-Fc) has more specific activity than when expressed in a Chinese hamster ovary cell line; its terminal halflife is 35 times higher than rhIFN- $\omega$ [130]. However, an obvious drawback of IFN- $\omega$ is that it requires daily subcutaneous administration, which might influence patients' compliance and impair its effectiveness. A proprietary delivery system (Omega DUROS® device) that is implanted subcutaneously and provides continuous drug delivery for 48 weeks is suggested to overcome this drawback [131]. In addition to the anti-HCV activities of IFN- $\alpha$ and IFN- $\omega$, a limited study showed that IFN- $\kappa$ has cell-associated antiviral effects against the HCV replicon [49]. Further research is needed to explore the antiviral activities of IFN- $\kappa$ in cell culture and in animal models.

IFN and HEV in humans. HEV, a non-enveloped positive-sense single-stranded RNA virus, is classified in the family Hepeviridae within the genus Orthohepevirus [132]. Until now, seven genotypes (gt) have been described, and gt 1 and 3 are found most frequently in humans [133]. Generally, HEV infections lead to arthralgia, vomiting, weakness, reduced appetite, abdominal pain, and hepatitis with accompanying symptoms, including jaundice and itching [134]. However, the antiviral treatment options for HEV infection is still limited. RVB has also been reported that have a broad spectrum antiviral activity against both RNA and DNA viruses. The treatment of RVB has also been demonstrated to efficiently inhibit HEV replication [135]. In addition, RBV cause SVRs in approximate seventy-five percent of the patients and it remains to be considered as first-choice therapy for most patients [136, 137]. Expect RVB, IFN- $\alpha$ is also proposed to be available compounds for treatments of HEV infections. It has been demonstrated that IFN- $\alpha 2 \mathrm{a}$ and IFN- $\alpha 2 \mathrm{~b}$ have the strongest antiviral activity against HEV of the 13 IFN- $\alpha$ subtypes [135]. Furthermore, IFN- $\alpha$ has a moderate and delayed anti-HEV effect in vitro and in patients, in contrast to its effect against HCV. Recently, researcher found that HEV is highly sensitive to pegIFN- $\alpha$ treatment in vivo. Although PegIFN- $\alpha$ resulted in SVRs in five patients with liver transplants who were infected with HEV, therapy with IFN- $\alpha 2$ a correlated with some side effects in organ transplant patients [139, 140]. As a result, this treatment is suitable only for well-selected patients with chronic HEV infections. No significant outcomes were observed after any IFN- $\alpha$ subtype was combined with ribavirin at a constant ribavirin dose of $25 \mu \mathrm{M}$, in one study [135]. Future studies are necessary for enhancing of the efficiencies and decreased side effects of antiviral agents and their combination. 


\section{Cellular Physiology Cell Physiol Biochem 2018;51:2377-2396

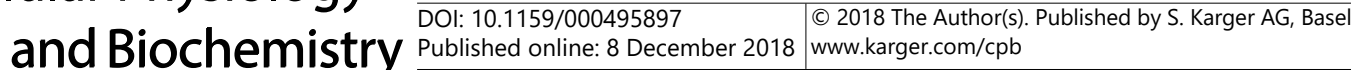 \\ Li et al.: The Biological Activities of Type I IFNs and Their Clinical Applications}

\section{Influenza Virus}

IFN- $\alpha$ and influenza virus. The epithelial cells of the upper respiratory tract are the primary sites of influenza infection. IAV infection induces expression of proinflammatory cytokines IL-1, IL-6, chemokines RANTES, monocyte chemotactic protein, tumor necrosis factor alpha, and IL-8 and limited amounts of type I IFNs IFN- $\alpha / \beta[141,142]$. Macrophages produce significant levels of IFN- $\alpha / \beta$, IL-1ß, TNF- $\alpha$, chemokines, and IL-18 [143]. IAV-infected DCs, especially plasmacytoid DCs, respond to influenza virus infection dose dependently, inducing high expression of IFN- $\alpha / \beta$ in spite of low-titer H1N1 influenza virus infection [144, 145]. High-titer H1N1 influenza virus infection stimulates rapid pDC apoptosis [146]. IFN- $\alpha$ suppresses acute influenza A virus replication and alleviates the excessive immunopathology caused by IAV [147]. IFN- $\alpha$ downregulates some effector mechanisms including IFN- $\gamma$ production by NK and $\mathrm{CD}^{+} \mathrm{T}$ cells through IL-10 production, and promotes rapid induction of an adaptive immune response [148]. The antiviral activities of IFN- $\alpha$ have been evaluated in vitro. Matzinger et al. [149] demonstrated induction of ISGs following systemic and mucosal administration of a recombinant PegIFN- $\alpha$ to Rhesus macaques. Induction was associated with reduced tracheal viral titers and systemic responses (fever, body weight) following infection with H1N1. Intranasal administration of ferret IFN- $\alpha$ reduced morbidity from H1N1 infection. In chickens, IFN- $\alpha$ treatment induced more rapid seroconversion than natural infection by low-pathogenicity influenza virus [150]. In addition, low-dose natural human IFN- $\alpha$ protects cynomolgus macaques from pulmonary tissue damage following administration to the buccal mucosa and decreases the alveolar inflammatory response when used at high oral dose [151]. IFN- $\alpha$ also promotes rapid induction of the antibody response and protective efficacy of influenza vaccine [152], these results indicates this kind of IFN can be a potent adjuvant for influenza vaccines.

The sensitivity of recognition of infect-targeted cells differs among influenza virus types. For instance, influenza B virus, which triggers early IFN responses directly via incoming viral particles before viral replication, transcription or protein synthesis are initiated, induces a faster IFN response than influenza A virus in human cells. Some studies, however, show that hosts affected with seasonal influenza A and B viruses have similar disease severities and localized immune responses [153-156]. In addition, the novel H7N9 virus shows a weak ability to induce host innate immune responses, while responses induced by the H5N1 virus are extremely strong in human primary moDCs [155]. A possible explanation for these differences is that early viral entry mechanisms lead to different activation of biological activities that contribute to viral clearance and clinical outcomes [157].

IFN- $\omega,-\tau$ and Influenza Virus. Human IFN- $\omega$ reduces levels of influenza viral load dose dependently in vivo, and daily intranasal treatment inhibits viral replication in lung tissues of guinea pigs [158]. The different antiviral effects of IFN- $\omega$ have been investigated with other IFNs. IFN- $\beta$ and IFN- $\omega$ show similar inhibitory activity against influenza virus at all IFN concentrations and both IFNs are significantly more potent at suppressing $\mathrm{Ca} / 04$ influenza virus infection than IFN- $\alpha$ at certain concentrations [158]. Another study suggested that IFN- $\omega$ activity was two times lower than IFN- $\beta 1$ a activity and somewhat lower than IFN- $\lambda 1$ and IFN- $\lambda 2$ activities [159]. However, IFN- $\omega$ has the most apparent antiviral activity on IFNstimulated A549 cells following infection with avian influenza virus. Although with less activity than IFN- $\beta 1$ a, IFN- $\lambda 1$, or IFN- $\lambda 2$, IFN- $\omega$ appears to be more efficient at reducing viral titers than IFN- $\alpha 2$ [159]. A study from Lachova et al. [160] showed that treatment of influenza-infected A549 cells with IFN- $\alpha$ and IFN- $\omega$ induces a similar amount of IFN- $\alpha$, IFN- $\beta$ and IFN- $\lambda$ mRNA but differs in induction of CXCL10 and RIG-1 mRNA. In addition to IFN- $\omega$, IFN- $\tau$ has biological effects against influenza virus. Studies show that single-dose intranasal administration of recombinant Ad5-IFN- $\tau$ effectively protects mice from mortality and disease from the highly virulent hv-PR8 influenza virus. The mechanism of protection is inducing specific and time-dependent phosphorylation of STAT1, increasing mRNA for ISG15, MX1, and OAS1 and preventing viral replication [44]. 


\section{Cellular Physiology Cell Physiol Biochem 2018;51:2377-2396 and Biochemistry \begin{tabular}{c|c} 
DOI: 10.1159/000495897 \\
Published
\end{tabular} \\ Li et al.: The Biological Activities of Type I IFNs and Their Clinical Applications}

\section{Conclusion}

Since their discovery about 60 years ago, IFNs have been used in available protocols for clinical treatment of viral diseases. IFN- $\alpha$, IFN- $\beta$ are currently used to treat hepatitis B and $C$ viral infections, and have effects against HEV infection and for chronic delta hepatitis. The first licensed interferon compound for use in cats for the treatment of FIV and FeLV infection, rFeIFN- $\omega$ has comparable efficacy when used for other diseases such as FCV and FHV-1. In addition, OIE suggests a combination of vaccines plus immunomodulatory or antiviral agents to trigger both innate and adaptive immune responses against some viral diseases such as foot and mouth disease. However, IFNs are not approved for preventing these or other viral infections. An important question is that the biological activities of these IFNs have so far not been evaluated in detail. In spite of combination therapy of IFN with ribavirin, especially pegylated IFN, a consensus IFN or albumin-IFN that showed more potency in improving efficacy and reducing side effects than IFN monotherapy, several issues such toxicity, refractory signalling and viral immune evasion still exist. The existence of large type I IFN classes in hosts may indicate they have a special function. Further future studies are urgently needed to determine these exact functions and the molecular mechanisms of their functional differences. In addition, in-depth investigations such as on the efficacy of doses and delivery modes of type I IFN subtypes are required to efficiently prevent some diseases.

\section{Abbreviations}

IFNs (Interferons); FeIFN- $\omega$ (feline IFN- $\omega$ ); HIV (human immunodeficiency virus); ISGs (IFN-stimulated genes); aa (amino acids); VV (vaccinia virus); TLRs (toll-like receptor); VEFG (vascular endothelial growth factor); GCSF (granulocyte colony-stimulating factor); ROS (reactive oxygen species); esIFN- $\kappa$ (Eptesicus serotinus interferon kappa); EBLV (European bat lyssavirus type 1); ART (antiretroviral therapy); AIDS (acquired immune deficiency syndrome); HDAC (histone deacetylation inhibitors); MIP- $1 \alpha$ (monocyte chemoattractant protein-1 $\alpha$ ); RANTES (normal T-cell expressed and secreted); DAA (directacting agents); TFs (transcription factors); RBV (Ribavirin); SVRs (sustained virological responses); IAV (Influenza A virus); PoIFN- $\delta 8$ (Porcine IFN- $\delta 8$ ); EqIFN- $\delta$ (Equine IFN- $\delta$ ); JAK-STAT (Janus kinase-Signal transducer and activator of transcription); pDC (plasmacytoid dendritic cells); CNC (Central nervous system); PBMC (peripheral blood mononuclear cell); HSV (herpes simplex virus); NDV (Newcastle disease virus); RSV (respiratory syncytial virus); VSV (vesicular stomatitis virus); SFV (swine fever virus); IDO (indoleamine 2, 3-dioxygenase); HCMV (human cytomegalovirus); SARS-CoV (SARS coronavirus); SIV (Simian Immunodeficiency Virus); MDBK (Madin-Darby bovine kidney(cells)); BHK-21 (baby hamster syrian kidney cells); BT (primary bovine testicular cells); PK-15 (porcine kidney cells); CDV (Canine distemper virus); CPV (canine parvovirus); FLV (Feline leukaemia virus); FIV (Feline Immunodeficiency virus); BVDV (bovine viral diarrhea virus); FCV (Feline Calicivirus); FHV-1 (Feline Herpesvirus-1); PRV (pseudorabies virus); PRRSV (Porcine reproductive and respiratory syndrome virus); HPV (Human Papillomavirus); DAXX (deathdomain associated protein-6); DAMPs (Damage Associated Molecular Pattern Molecules); PAMPs (Pathogen-associated molecular patterns); KIR2DS2 (killer immunoglobulin-like receptor 2DS2); FMDV (foot and mouth disease virus); EMCV (encephalomyocarditis virus); MHV (murine hepatitis virus); CTL (cytotoxic lymphocyte); MHC (major histocompatibility complex); OIE (World Organization for Animal Health). 


\section{Cellular Physiology Cell Physiol Biochem 2018;51:2377-2396 and Biochemistry Published $\begin{aligned} & \text { DOI: 10.1159/000495897 } \\ & \text { (c) } 2018 \text { The Author(s). Published by S. Karger AG, Basel } \\ & \text { www.karger.com/cpb }\end{aligned}$

\section{Acknowledgements}

This work was supported by the National Key Research and Development Program (2017YFD0500902), the Key R\&D Program of Gansu Province of China (Grant No. 17YF1NA070) and the National Pig Industrial System of China (CARS-36-06B).

\section{Disclosure Statement}

The authors declare no conflicts of interest.

\section{References}

1 Isaacs A, Lindenmann J, Valentine Rc: Virus interference. II. Some properties of interferon. Proc R Soc Lond B Biol Sci 1957;147:268-273.

2 Lin FC, Young HA: Interferons: Success in anti-viral immunotherapy. Cytokine Growth Factor Rev 2014:25:369-376.

3 Zhou H, Chen S, Wang M, Cheng A: Interferons and their receptors in birds: a comparison of gene structure, phylogenetic analysis, and cross modulation. Int J Mol Sci 2014;15:21045-21068.

4 Li SF, Zhao FR, Shao JJ, Xie YL, Chang HY, Zhang YG: Interferon-omega: Current status in clinical applications. Int Immunopharmacol 2017;52:253-260.

5 Tasker C, Subbian S, Gao P, Couret J, Levine C, Ghanny S, Soteropoulos P, Zhao X, Landau N, Lu W, Chang TL: IFN-epsilon protects primary macrophages against HIV infection. JCI Insight 2016;1:e88255.

-6 Chon TW, Bixler S: Interferon-tau: current applications and potential in antiviral therapy. J Interferon Cytokine Res 2010;30:477-485.

7 Lefevre F, Guillomot M, D’Andrea S, Battegay S, La Bonnardiere C: Interferon-delta: the first member of a novel type I interferon family. Biochimie 1998;80:779-788.

8 Zwarthoff EC, Mooren AT, Trapman J: Organization, structure and expression of murine interferon alpha genes. Nucleic Acids Res 1985;13:791-804.

-9 Hardy MP, Owczarek CM, Jermiin LS, Ejdeback M, Hertzog PJ: Characterization of the type I interferon locus and identification of novel genes. Genomics 2004; 84:331-345.

10 De Maeyer E and De Maeyer-Guignard J: Type I interferons. Int Rev Immunol 1998;17:53-73.

11 Owczarek CM, Hwang SY, Holland KA, Gulluyan LM, Tavaria M, Weaver B, Reich NC, Kola I, Hertzog PJ: Cloning and characterization of soluble and transmembrane isoforms of a novel component of the murine type I interferon receptor, IFNAR 2. J Biol Chem 1997;272:23865-23870.

12 Zan J, Zhang H, Gu AP, Zhong KL, Lu MY, Bai XX, Zhang JY, Cai J: Yin Yang 1 Dynamically Regulates Antiviral Innate Immune Responses During Viral Infection. Cell Physiol Biochem 2017;44:607-617.

13 Maney SK, Xu HC, Huang J, Pandyra AA, Ehlting C, Aguilar-Valenzuela R, Pozdeev VI, Mcllwain DR, Zimmermann A, Bode JG, Hengel H, Kirschning CJ, Kim IR, Hiscott J, Brenner D, Häussinger D, Ohashi PS, Mak TW, Lang KS, Lang PA: RAIDD Mediates TLR3 and IRF7 Driven Type I Interferon Production. Cell Physiol Biochem 2016;39:1271-1280.

14 Cui H, Liu Y, Huang Y: Roles of TRIM32 in Corneal Epithelial Cells After Infection with Herpes Simplex Virus. Cell Physiol Biochem 2017;43:801-811.

15 Zhao LJ, He SF, Liu Y, Zhao P, Bian ZQ, Qi ZT: Inhibition of STAT Pathway Impairs Anti-Hepatitis C Virus Effect of Interferon Alpha. Cell Physiol Biochem 2016;40:77-90.

16 Gibbert K, Schlaak JF, Yang D, Dittmer U: IFN-alpha subtypes: distinct biological activities in anti-viral therapy. Br J Pharmacol 2013;168:1048-1058.

17 Pinto LA, Blazevic V, Patterson BK, Mac TC, Dolan MJ, Shearer GM: Inhibition of human immunodeficiency virus type 1 replication prior to reverse transcription by influenza virus stimulation. J Virol 2000; 74:45054511.

18 Diamond MS, Roberts TG, Edgil D, Lu B, Ernst J, Harris E: Modulation of Dengue virus infection in human cells by alpha, beta, and gamma interferons. J Virol 2000;74:4957-4966. 


\section{Cellular Physiology Cell Physiol Biochem 2018;51:2377-2396 \begin{tabular}{l|l|l|l} 
DOI: 10.1159/000495897 & 2018 The Author(s). Published by S. Karger AG, Basel
\end{tabular} and Biochemistry Published onlıne: 8 December 2018 www.karger.com/cpb}

19 Zhang X, Ye Z, Pei Y, Qiu G, Wang Q Xu Y, Shen B, Zhang J: Neddylation is required for herpes simplex virus type I (HSV-1)-induced early phase interferon-beta production. Cell Mol Immunol 2016;13:578-583.

-20 Konde MK, Baker DP, Traore FA, Sow MS, Camara A, Barry AA, Mara D, Barry A, Cone M, Kaba I, Richard AA, Beavogui AH, Gunther S, Pintilie M, Fish EN: Interferon beta-1a for the treatment of Ebola virus disease: A historically controlled, single-arm proof-of-concept trial. Plos One 2017;12:e169255.

-21 Veazey RS, Pilch-Cooper HA, Hope TJ, Alter G, Carias AM, Sips M, Wang X, Rodriguez B, Sieg SF, Reich A, Wilkinson P, Cameron MJ, Lederman MM: Prevention of SHIV transmission by topical IFN-beta treatment. Mucosal Immunol 2016;9:1528-1536.

-22 Frumence E, Roche M, Krejbich-Trotot P, El-Kalamouni C, Nativel B, Rondeau P, Misse D, Gadea G, Viranaicken W, Despres P: The South Pacific epidemic strain of Zika virus replicates efficiently in human epithelial A549 cells leading to IFN-beta production and apoptosis induction. Virology 2016;493:217-226.

23 Guo Y, Gao M, Bao J, Luo X, Liu Y, An D, Zhang H, Ma B, Wang J: Molecular cloning and characterization of a novel bovine IFN-epsilon. Gene 2015;558:25-30.

24 Demers A, Kang G, Ma F, Lu W, Yuan Z, Li Y, Lewis M, Kraiselburd EN, Montaner L, Li Q: The mucosal expression pattern of interferon-epsilon in rhesus macaques. J Leukoc Biol 2014;96:1101-1107.

25 Yang L, Xu L, Li Y, Li J, Bi Y, Liu W: Molecular and functional characterization of canine interferon-epsilon. J Interferon Cytokine Res 2013;33:760-768.

26 Day SL, Ramshaw IA, Ramsay AJ, Ranasinghe C: Differential effects of the type I interferons alpha4, beta, and epsilon on antiviral activity and vaccine efficacy. J Immunol 2008;180:7158-7166.

27 Peng FW, Duan ZJ, Zheng LS, Xie ZP, Gao HC, Zhang H, Li WP, Hou YD: Purification of recombinant human interferon-epsilon and oligonucleotide microarray analysis of interferon-epsilon-regulated genes. Protein Expr Purif 2007;53:356-362.

28 An D, Guo Y, Bao J, Luo X, Liu Y, Ma B, Gao M, Wang J: Molecular characterization and biological activity of bovine interferon-omega3. Res Vet Sci 2017;115:125-131.

29 Hagelstein J, Kist A, Stremmel W, Galle PR: Antiviral potential of interferon-omega on hepatitis B virus replication in human hepatoma cells. Arzneimittelforschung 1998;48:343-347.

-30 Okuse C, Rinaudo JA, Farrar K, Wells F, Korba BE: Enhancement of antiviral activity against hepatitis C virus in vitro by interferon combination therapy. Antiviral Res 2005;65:23-34.

-31 Wang Y, Li X, Song S, Sun Y, Zhang J, Yu C, Chen W: HPV11 E6 mutation by overexpression of APOBEC3A and effects of interferon- $\omega$ on APOBEC3s and HPV11 E6 expression in HPV11 HaCaT cells. Virol J 2017;14:211.

-32 Zhao X, Cheng G, Yan W, Liu M, He Y, Zheng Z: Characterization and virus-induced expression profiles of the porcine interferon-omega multigene family. J Interferon Cytokine Res 2009;29:687-693.

33 Cochet M, Vaiman D, Lefevre F: Novel interferon delta genes in mammals: cloning of one gene from the sheep, two genes expressed by the horse conceptus and discovery of related sequences in several taxa by genomic database screening. Gene 2009;433:88-99.

-34 Detournay 0, Morrison DA, Wagner B, Zarnegar B, Wattrang E: Genomic analysis and mRNA expression of equine type I interferon genes. J Interferon Cytokine Res 2013;33:746-759.

-35 Sang Y, Rowland RR, Hesse RA, Blecha F: Differential expression and activity of the porcine type I interferon family. Physiol Genomics 2010;42:248-258.

-36 Zhao X, Cheng G, Jiao Y, Yan W, Liu M, Zheng Z: Cloning and characterization of porcine interferon-deltarelated genes identified by genomic database screening. J Interferon Cytokine Res 2012;32:378-385.

-37 Johnson JA, Hochkeppel HK, Gangemi JD: IFN-tau exhibits potent suppression of human papillomavirus E6/ E7 oncoprotein expression. J Interferon Cytokine Res 1999;19:1107-1116.

-38 Kohara J, Yokomizo Y: In vitro and in vivo effects of recombinant bovine interferon-tau on bovine leukemia virus. J Vet Med Sci 2007;69:15-19.

-39 Kohara J, Nishikura Y, Konnai S, Tajima M, Onuma M: Effects of interferon-tau on cattle persistently infected with bovine viral diarrhea virus. JPN J Vet Res 2012;60:63-70.

40 Usharani J, Park SY, Cho EJ, Kim C, Ko YJ, Tark D, Kim SM, Park JH, Lee KN, Lee MH, Lee HS: Antiviral activity of ovine interferon tau 4 against foot-and-mouth disease virus. Antiviral Res 2017;143:134-141.

41 Tennakoon DK, Smith R, Stewart MD, Spencer TE, Nayak M, Welsh CJ: Ovine IFN-tau modulates the expression of MHC antigens on murine cerebrovascular endothelial cells and inhibits replication of Theiler's virus. J Interferon Cytokine Res 2001;21:785-792. 


\section{Cellular Physiology Cell Physiol Biochem 2018;51:2377-2396 \begin{tabular}{l|l|l|l} 
DOI: 10.1159/000495897 2018 The Author(s). Published by S. Karger AG, Basel & (c)
\end{tabular} and Biochemistry

42 Takahashi T, Sakumoto R, Hayashi KG, Hosoe M, Shirai J, Hashizume K: Generation of recombinant bovine interferon tau in the human embryonic kidney cell line and its biological activity. Anim Sci J 2017;88:14981505.

-43 Pontzer CH, Yamamoto JK, Bazer FW, Ott TL, Johnson HM: Potent anti-feline immunodeficiency virus and anti-human immunodeficiency virus effect of IFN-tau. J Immunol 1997;158:4351-4357.

\$4 Martin V, Pascual E, Avia M, Rangel G, de Molina A, Alejo A, Sevilla N: A Recombinant Adenovirus Expressing Ovine Interferon Tau Prevents Influenza Virus-Induced Lethality in Mice. J Virol 2016;90:3783-3788.

$\checkmark 45$ Nakajima A, Sokawa Y: Induction of blood 2',5'-oligoadenylate synthetase activity in mice by gastric administration of ovine IFN-tau. J Interferon Cytokine Res 2002;22:397-402.

\$6 Reiser J, Hurst J, Voges M, Krauss P, Munch P, Iftner T, Stubenrauch F: High-risk human papillomaviruses repress constitutive kappa interferon transcription via E6 to prevent pathogen recognition receptor and antiviral-gene expression. J Virol 2011;85:11372-11380.

47 Santhakumar D, Iqbal M, Nair V, Munir M: Chicken IFN Kappa: A Novel Cytokine with Antiviral Activities. Sci Rep 2017;7:2719.

48 He X, Korytar T, Schatz J, Freuling CM, Muller T, Kollner B: Anti-lyssaviral activity of interferons kappa and omega from the serotine bat, Eptesicus serotinus. J Virol 2014;88:5444-5454.

49 Buontempo PJ, Jubin RG, Buontempo CA, Wagner NE, Reyes GR, Baroudy BM: Antiviral activity of transiently expressed IFN-kappa is cell-associated. J Interferon Cytokine Res 2006;26:40-52.

50 Habiger C, Jager G, Walter M, Iftner T, Stubenrauch F: Interferon Kappa Inhibits Human Papillomavirus 31 Transcription by Inducing Sp100 Proteins. J Virol 2015;90:694-704.

51 Guo Y, An D, Liu Y, Bao J, Luo X, Cheng X, Wang Y, Gao M, Wang J: Characterization and signaling pathway analysis of interferon-kappa in bovine. Dev Comp Immunol 2017;67:213-220.

52 Kawamoto S, Oritani K, Asakura E, Ishikawa J, Koyama M, Miyano K, Iwamoto M, Yasuda S, Nakakubo H, Hirayama F, Ishida N, Ujiie H, Masaie H, Tomiyama Y: A new interferon, limitin, displays equivalent immunomodulatory and antitumor activities without myelosuppressive properties as compared with interferon-alpha. Exp Hematol 2004;32:797-805.

-53 Kawamoto S, Oritani K, Asada H, Takahashi I, Ishikawa J, Yoshida H, Yamada M, Ishida N, Ujiie H, Masaie H, Tomiyama Y, Matsuzawa Y: Antiviral activity of limitin against encephalomyocarditis virus, herpes simplex virus, and mouse hepatitis virus: diverse requirements by limitin and alpha interferon for interferon regulatory factor 1. J Virol 2003;77:9622-9631.

54 Walter MR, Bordens R, Nagabhushan TL, Williams BR, Herberman RB, Dinarello CA, Borden EC, Trotta PP, Pestka S, Pfeffer LM: Review of recent developments in the molecular characterization of recombinant alfa interferons on the 40th anniversary of the discovery of interferon. Cancer Biother Radiopharm 1998;13:143-154.

55 Diaz MO, Bohlander S, Allen G: Nomenclature of the human interferon genes. J Interferon Res 1994;14:221222.

56 Nyman TA, Kalkkinen N, Tolo H, Helin J: Structural characterisation of N-linked and O-linked oligosaccharides derived from interferon-alpha2b and interferon-alpha14c produced by Sendai-virusinduced human peripheral blood leukocytes. Eur J Biochem 1998;253:485-493.

57 Reis LF, Ho LT, Vilcek J: Tumor necrosis factor acts synergistically with autocrine interferon-beta and increases interferon-beta mRNA levels in human fibroblasts. J Biol Chem 1989;264:16351-16354.

58 Sekellick MJ, Marcus PI: Interferon induction by viruses. VIII. Vesicular stomatitis virus: [+/-]DI-011 particles induce interferon in the absence of standard virions. Virology 1982;117:280-285.

59 Lavoie TB, Kalie E, Crisafulli-Cabatu S, Abramovich R, DiGioia G, Moolchan K, Pestka S, Schreiber G: Binding and activity of all human alpha interferon subtypes. Cytokine 2011;56:282-289.

60 Moraga I, Harari D, Schreiber G, Uze G, Pellegrini S: Receptor density is key to the alpha2/beta interferon differential activities. Mol Cell Biol 2009;29:4778-4787.

61 Easlick J, Szubin R, Lantz S, Baumgarth N, Abel K: The early interferon alpha subtype response in infant macaques infected orally with SIV. J Acquir Immune Defic Syndr 2010;55:14-28.

-62 Severa M, Remoli ME, Giacomini E, Ragimbeau J, Lande R, Uze G, Pellegrini S, Coccia EM: Differential responsiveness to IFN-alpha and IFN-beta of human mature DC through modulation of IFNAR expression. J Leukoc Biol 2006;79:1286-1294.

-63 Schoggins JW, Rice CM: Interferon-stimulated genes and their antiviral effector functions. Curr Opin Virol 2011;1:519-525. 


\section{Cellular Physiology Cell Physiol Biochem 2018;51:2377-2396 \begin{tabular}{l|l|l|l} 
DOI: 10.1159/000495897 & 2018 The Author(s). Published by S. Karger AG, Basel
\end{tabular} and Biochemistry

64 Fung KY, Mangan NE, Cumming H, Horvat JC, Mayall JR, Stifter SA, De Weerd N, Roisman LC, Rossjohn J, Robertson SA, Schjenken JE, Parker B, Gargett CE, Nguyen HP, Carr DJ, Hansbro PM, Hertzog PJ: Interferonepsilon protects the female reproductive tract from viral and bacterial infection. Science 2013;339:10881092.

65 Matsumiya T, Prescott SM, Stafforini DM: IFN-epsilon mediates TNF-alpha-induced STAT1 phosphorylation and induction of retinoic acid-inducible gene-I in human cervical cancer cells. J Immunol 2007;179:45424549.

66 Matsumiya T, Xing F, Ebina M, Hayakari R, Imaizumi T, Yoshida H, Kikuchi H, Topham MK, Satoh K, Stafforini DM: Novel role for molecular transporter importin 9 in posttranscriptional regulation of IFN-epsilon expression. J Immunol 2013;191:1907-1915.

67 Stifter SA, Matthews AY, Mangan NE: Defining the distinct, intrinsic properties of the novel type I interferon, IFN $\epsilon$. J Biol Chem 2018;293:3168-3179.

68 Adolf GR: Human interferon omega--a review. Mult Scler 1995;S44-S47.

69 Yang LM, Xue QH, Sun L, Zhu YP, Liu WJ: Cloning and characterization of a novel feline IFN-omega. J Interferon Cytokine Res 2007;27:119-127.

70 Roberts RM, Liu L, Alexenko A: New and atypical families of type I interferons in mammals: comparative functions, structures, and evolutionary relationships. Prog Nucleic Acid Res Mol Biol 1997;56:287-325.

71 Domenech A, Miro G, Collado VM, Ballesteros N, Sanjose L, Escolar E, Martin S, Gomez-Lucia E: Use of recombinant interferon omega in feline retrovirosis: from theory to practice. Vet Immunol Immunopathol 2011;143:301-306.

72 Gil S, Leal RO, McGahie D, Sepulveda N, Duarte A, Niza MM, Tavares L: Oral Recombinant Feline InterferonOmega as an alternative immune modulation therapy in FIV positive cats: clinical and laboratory evaluation. Res Vet Sci 2014;96:79-85.

73 De Mari K, Maynard L, Sanquer A, Lebreux B, Eun HM: Therapeutic effects of recombinant feline interferonomega on feline leukemia virus (FeLV)-infected and FeLV/feline immunodeficiency virus (FIV)-coinfected symptomatic cats. J Vet Intern Med 2004;18:477-482.

74 Leal RO, Gil S, Sepulveda N, McGahie D, Duarte A, Niza MM, Tavares L: Monitoring acute phase proteins in retrovirus infected cats undergoing feline interferon-omega therapy. J Small Anim Pract 2014;55:39-45.

75 Leal RO, Gil S, Duarte A, McGahie D, Sepulveda N, Niza MM, Tavares L: Evaluation of viremia, proviral load and cytokine profile in naturally feline immunodeficiency virus infected cats treated with two different protocols of recombinant feline interferon omega. Res Vet Sci 2015;99:87-95.

76 Villaverde MS, Gil-Cardeza ML, Glikin GC, Finocchiaro LM: Interferon-beta lipofection II. Mechanisms involved in cell death and bystander effect induced by cationic lipid-mediated interferon-beta gene transfer to human tumor cells. Cancer Gene Ther 2012;19:420-430.

-77 Villaverde MS, Targovnik AM, Miranda MV, Finocchiaro LM, Glikin GC: Cytotoxic effects induced by interferon-omega gene lipofection through ROS generation and mitochondrial membrane potential disruption in feline mammary carcinoma cells. Cytokine 2016;84:47-55.

78 LaFleur DW, Nardelli B, Tsareva T, Mather D, Feng P, Semenuk M, Taylor K, Buergin M, Chinchilla D, Roshke V, Chen G, Ruben SM, Pitha PM, Coleman TA, Moore PA: Interferon-kappa, a novel type I interferon expressed in human keratinocytes. J Biol Chem 2001;276:39765-39771.

79 DeCarlo CA, Severini A, Edler L, Escott NG, Lambert PF, Ulanova M, Zehbe I: IFN-kappa, a novel type I IFN, is undetectable in HPV-positive human cervical keratinocytes. Lab Invest 2010;90:1482-1491.

80 Roberts RM: Interferon-tau, a Type 1 interferon involved in maternal recognition of pregnancy. Cytokine Growth Factor Rev 2007;18:403-408.

81 Whaley AE, Meka CS, Harbison LA, Hunt JS, Imakawa K: Identification and cellular localization of unique interferon mRNA from human placenta. J Biol Chem 1994;269:10864-10868.

82 Duc-Goiran P, Robert-Galliot B, Lopez J, Chany C: Unusual apparently constitutive interferons and antagonists in human placental blood. Proc Natl Acad Sci U S A 1985;82:5010-5014.

83 Leaman DW, Roberts RM: Genes for the trophoblast interferons in sheep, goat, and musk ox and distribution of related genes among mammals. J Interferon Res 1992;12:1-11.

-84 Pontzer CH, Ott TL, Bazer FW, Johnson HM: Structure/function studies with interferon tau: evidence for multiple active sites. J Interferon Res 1994;14:133-141.

-85 Ealy AD, Green JA, Alexenko AP, Keisler DH, Roberts RM: Different ovine interferon-tau genes are not expressed identically and their protein products display different activities. Biol Reprod 1998;58:566-573. 


\section{Cellular Physiology Cell Physiol Biochem 2018;51:2377-2396 \begin{tabular}{l|l|l|l} 
DOI: 10.1159/000495897 2018 The Author(s). Published by S. Karger AG, Basel & (c)
\end{tabular} and Biochemistry

-86 Ealy AD, Larson SF, Liu L, Alexenko AP, Winkelman GL, Kubisch HM, Bixby JA, Roberts RM: Polymorphic forms of expressed bovine interferon-tau genes: relative transcript abundance during early placental development, promoter sequences of genes and biological activity of protein products. Endocrinology 2001;142:2906-2915.

-87 Tanikawa N, Seno K, Kawahara-Miki R, Kimura K, Matsuyama S, Iwata H, Kuwayama T, Shirasuna K: Interferon Tau Regulates Cytokine Production and Cellular Function in Human Trophoblast Cell Line. J Interferon Cytokine Res 2017;37:456-466.

-88 Soos JM, Subramaniam PS, Hobeika AC, Schiffenbauer J, Johnson HM: The IFN pregnancy recognition hormone IFN-tau blocks both development and superantigen reactivation of experimental allergic encephalomyelitis without associated toxicity. J Immunol 1995;155:2747-2753.

-89 Oritani K, Medina KL, Tomiyama Y, Ishikawa J, Okajima Y, Ogawa M, Yokota T, Aoyama K, Takahashi I, Kincade PW, Matsuzawa Y: Limitin: An interferon-like cytokine that preferentially influences B-lymphocyte precursors. Nat Med 2000;6:659-666.

90 Oritani K, Kincade PW, Zhang C, Tomiyama Y, Matsuzawa Y: Type I interferons and limitin: a comparison of structures, receptors, and functions. Cytokine Growth Factor Rev 2001;12:337-348.

-91 Ishida N, Oritani K, Shiraga M, Yoshida H, Kawamoto S, Ujiie H, Masaie H, Ichii M, Tomiyama Y, Kanakura Y: Differential effects of a novel IFN-zeta/limitin and IFN-alpha on signals for Daxx induction and Crk phosphorylation that couple with growth control of megakaryocytes. Exp Hematol 2005;33:495-503.

-92 Oritani K, Hirota S, Nakagawa T, Takahashi I, Kawamoto S, Yamada M, Ishida N, Kadoya T, Tomiyama Y, Kincade PW, Matsuzawa Y: T lymphocytes constitutively produce an interferonlike cytokine limitin characterized as a heat- and acid-stable and heparin-binding glycoprotein. Blood 2003;101:178-185.

-93 Sun H, Buzon MJ, Shaw A, Berg RK, Yu XG, Ferrando-Martinez S, Leal M, Ruiz-Mateos E, Lichterfeld M: Hepatitis C therapy with interferon-alpha and ribavirin reduces CD4 T-cell-associated HIV-1 DNA in HIV-1/ hepatitis C virus-coinfected patients. J Infect Dis 2014;209:1315-1320.

-94 Emilie D, Burgard M, Lascoux-Combe C, Laughlin M, Krzysiek R, Pignon C, Rudent A, Molina JM, Livrozet JM, Souala F, Chene G, Grangeot-Keros L, Galanaud P, Sereni D, Rouzioux C: Early control of HIV replication in primary HIV-1 infection treated with antiretroviral drugs and pegylated IFN alpha: results from the Primoferon A (ANRS 086) Study. Aids 2001;15:1435-1437.

$\$ 95$ Shepherd FA, Beaulieu R, Gelmon K, Thuot CA, Sawka C, Read S, Singer J: Prospective randomized trial of two dose levels of interferon alfa with zidovudine for the treatment of Kaposi's sarcoma associated with human immunodeficiency virus infection: a Canadian HIV Clinical Trials Network study. J Clin Oncol 1998; 16:1736-1742.

-96 Asmuth DM, Murphy RL, Rosenkranz SL, Lertora JJ, Kottilil S, Cramer Y, Chan ES, Schooley RT, Rinaldo CR, Thielman N, Li XD, Wahl SM, Shore J, Janik J, Lempicki RA, Simpson Y, Pollard RB; AIDS Clinical Trials Group A5192 Team: Safety, tolerability, and mechanisms of antiretroviral activity of pegylated interferon Alfa-2a in HIV-1-monoinfected participants: a phase II clinical trial. J Infect Dis 2010;201:1686-1696.

\$7 Harper MS, Guo K, Gibbert K, Lee EJ, Dillon SM, Barrett BS, McCarter MD, Hasenkrug KJ, Dittmer U, Wilson CC, Santiago ML: Interferon-alpha Subtypes in an Ex Vivo Model of Acute HIV-1 Infection: Expression, Potency and Effector Mechanisms. Plos Pathog 2015;11:e1005254.

-98 van Grevenynghe J, Cubas RA, Noto A, DaFonseca S, He Z, Peretz Y, Filali-Mouhim A, Dupuy FP, Procopio FA, Chomont N, Balderas RS, Said EA, Boulassel MR, Tremblay CL, Routy JP, Sékaly RP, Haddad EK: Loss of memory B cells during chronic HIV infection is driven by Foxo3a- and TRAIL-mediated apoptosis. J Clin Invest 2011;121:3877-3888.

-99 Ambrus JS, Dembinski W, Chadha K, Ambrus JJ, Chadha KC: Resistance to interferons. Discov Med 2004;4:310-314.

100 Utay NS, Douek DC: Interferons and HIV Infection: The Good, the Bad, and the Ugly. Pathog Immun 2016;1:107-116.

101 Spivak AM, Planelles V: Novel Latency Reversal Agents for HIV-1 Cure. Annu Rev Med. 2018;69:421-436.

102 Bam RA, Hansen D, Irrinki A, Mulato A, Jones GS, Hesselgesser J, Frey CR, Cihlar T, Yant SR: TLR7 Agonist GS-9620 Is a Potent Inhibitor of Acute HIV-1 Infection in Human Peripheral Blood Mononuclear Cells. Antimicrob Agents Chemother 2016;61.

-103 Buitendijk M, Eszterhas SK, Howell AL: Gardiquimod: a Toll-like receptor-7 agonist that inhibits HIV type 1 infection of human macrophages and activated T cells. AIDS Res Hum Retroviruses 2013;29:907-918. 


\section{Cellular Physiology Cell Physiol Biochem 2018;51:2377-2396 \begin{tabular}{l|l|l|l} 
DOI: 10.1159/000495897 & 2018 The Author(s). Published by S. Karger AG, Basel
\end{tabular} and Biochemistry Published online: 8December 2018 www.karger.com/cpb}

104 Kotenko SV, Gallagher G, Baurin VV, Lewis-Antes A, Shen M, Shah NK, Langer JA, Sheikh F, Dickensheets H, Donnelly RP: IFN-lambdas mediate antiviral protection through a distinct class II cytokine receptor complex. Nat Immunol 2003;4:69-77

105 Donnelly RP, Kotenko SV: Interferon-lambda: a new addition to an old family. J Interferon Cytokine Res 2010;30:555-564.

106 Doyle SE, Schreckhise H, Khuu-Duong K, Henderson K, Rosler R, Storey H, Yao L, Liu H, Barahmand-pour F, Sivakumar P, Chan C, Birks C, Foster D, Clegg CH, Wietzke Braun P, Mihm S, Klucher KM: Interleukin-29 uses a type 1 interferon-like program to promote antiviral responses in human hepatocytes. Hepatology 2006;44:896-906.

107 Muir AJ, Shiffman ML, Zaman A, Yoffe B, de la Torre A, Flamm S, Gordon SC, Marotta P, Vierling JM, LopezTalavera JC, Byrnes-Blake K, Fontana D, Freeman J, Gray T, Hausman D, Hunder NN, Lawitz E: Phase 1b study of pegylated interferon lambda 1 with or without ribavirin in patients with chronic genotype 1 hepatitis C virus infection. Hepatology 2010;52:822-832.

108 Ramos EL: Preclinical and clinical development of pegylated interferon-lambda 1 in chronic hepatitis C. J Interferon Cytokine Res 2010;30:591-595.

109 Vishwanathan SA, Guenthner PC, Lin CY, Dobard C, Sharma S, Adams DR, Otten RA, Heneine W, Hendry RM, McNicholl JM, Kersh EN: High susceptibility to repeated, low-dose, vaginal SHIV exposure late in the luteal phase of the menstrual cycle of pigtail macaques. J Acquir Immune Defic Syndr 2011;57:261-264.

110 Curlin ME, Leelawiwat W, Dunne EF, Chonwattana W, Mock PA, Mueanpai F, Thep-Amnuay S, Whitehead SJ, McNicholl JM: Cyclic changes in HIV shedding from the female genital tract during the menstrual cycle. J Infect Dis 2013;207:1616-1620.

111 Abdulhaqq SA, Zorrilla C, Kang G, Yin X, Tamayo V, Seaton KE, Joseph J, Garced S, Tomaras GD, Linn KA, Foulkes AS, Azzoni L, VerMilyea M, Coutifaris C, Kossenkov AV, Showe L, Kraiselburd EN, Li Q, Montaner LJ: HIV-1-negative female sex workers sustain high cervical IFNvarepsilon, low immune activation, and low expression of HIV-1-required host genes. Mucosal Immunol 2016;9:1027-1038.

112 Garcia-Minambres A, Eid SG, Mangan NE, Pade C, Lim SS, Matthews AY, de Weerd NA, Hertzog PJ, Mak J: Interferon epsilon promotes HIV restriction at multiple steps of viral replication. Immunol Cell Biol 2017;95:478-483.

113 Rogez-Kreuz C, Maneglier B, Martin M, Dereuddre-Bosquet N, Martal J, Dormont D, Clayette P: Involvement of IL-6 in the anti-human immunodeficiency virus activity of IFN-tau in human macrophages. Int Immunol 2005;17:1047-1057.

114 Rogez C, Martin M, Dereuddre-Bosquet N, Martal J, Dormont D, Clayette P: Anti-human immunodeficiency virus activity of tau interferon in human macrophages: involvement of cellular factors and betachemokines. J Virol 2003;77:12914-12920.

115 Maneglier B, Rogez-Kreuz C, Dereuddre-Bosquet N, Martal J, Devillier P, Dormont D, Clayette P: Anti-HIV effects of IFN-tau in human macrophages: role of cellular antiviral factors and interleukin-6. Pathol Biol 2008;56:492-503.

116 Rogez-Kreuz C, Maneglier B, Dereuddre-Bosquet N, Dormont D, Clayette P: Lack of IFN-gamma production in response to antigenic stimulation in human IFN-tau-treated lymphocytes. J Interferon Cytokine Res 2005;25:444-452.

117 Tuo W, MacMillan H, Gunter N, Bazer FW, Brown WC: Upregulation of interleukin-4 and IFN-gamma expression by IFN-tau, a member of the type I IFN family. J Interferon Cytokine Res 1999;19:179-187.

$\checkmark 118$ Ballin AC, Schulz B, Helps C, Sauter-Louis C, Mueller RS, Hartmann K: Limited efficacy of topical recombinant feline interferon-omega for treatment of cats with acute upper respiratory viral disease. Vet J 2014;202:466-470.

119 Ceron JJ, Eckersall PD, Martynez-Subiela S: Acute phase proteins in dogs and cats: current knowledge and future perspectives. Vet Clin Pathol 2005;34:85-99.

120 Leal RO, Gil S: The Use of Recombinant Feline Interferon Omega Therapy as an Immune-Modulator in Cats Naturally Infected with Feline Immunodeficiency Virus: New Perspectives. Vet Sci 2016;3.

121 Goyal A, Murray JM: Cost-Effectiveness of Peg-Interferon, Interferon and Oral Nucleoside Analogues in the Treatment of Chronic Hepatitis B and D Infections in China. Clin Drug Investig 2016;36:637-648.

122 Lee S, Kim IH, Kim SH, Kim SW, Lee SO, Lee ST, Kim DG, Lee CS, Choi CS, Cho EY, Kim HC: Efficacy and tolerability of pegylated interferon-alpha2a plus ribavirin versus pegylated interferon-alpha2b plus ribavirin in treatment-naive chronic hepatitis C patients. Intervirology 2010;53:146-153. 


\section{Cellular Physiology Cell Physiol Biochem 2018;51:2377-2396 \begin{tabular}{l|l|l} 
and Biochemistry Published online: 8December 2018 & $\begin{array}{l}\text { ○ } 2018 \text { The Author(s). Published by S. Karger AG, Basel } \\
\text { www.karger.com/cpb }\end{array}$ \\
\hline
\end{tabular}}

123 Todt D, Francois C, Anggakusuma, Behrendt P, Engelmann M, Knegendorf L, Vieyres G, Wedemeyer H, Hartmann R, Pietschmann T, Duverlie G, Steinmann E: Antiviral Activities of Different Interferon Types and Subtypes against Hepatitis E Virus Replication. Antimicrob Agents Chemother 2016;60:2132-2139.

124 Koyama T, Sakamoto N, Tanabe Y, Nakagawa M, Itsui Y, Takeda Y, Kakinuma S, Sekine Y, Maekawa S, Yanai Y, Kurimoto M, Watanabe M: Divergent activities of interferon-alpha subtypes against intracellular hepatitis C virus replication. Hepatol Res 2006;34:41-49.

125 Dubois A, Francois C, Descamps V, Fournier C, Wychowski C, Dubuisson J, Castelain S, Duverlie G: Enhanced anti-HCV activity of interferon alpha 17 subtype. Virol J 2009;6:70.

-126 Rivero-Juarez A, Gonzalez R, Frias M, Manzanares-Martin B, Rodriguez-Cano D, Perez-Camacho I, Gordon A, Cuenca F, Camacho A, Pineda JA, Pena J, Rivero A: KIR2DS2 as predictor of thrombocytopenia secondary to pegylated interferon-alpha therapy. Pharmacogenomics J 2017;17:360-365.

127 Keshvari M, Alavian SM, Sharafi H, Karimi G, Gholami FM: Interferon alpha-2b therapy in chronic hepatitis delta. Hepat Mon 2014;14:e15729.

128 Buckwold VE, Lang W, Scribner C, Blanchett D, Alessi T, Langecker P: Safety pharmacology, toxicology and pharmacokinetic assessment of recombinant human omega-interferon produced from CHO-SS cells. Basic Clin Pharmacol Toxicol 2006;99:62-70.

129 Buckwold VE, Wei J, Huang Z, Huang C, Nalca A, Wells J, Russell J, Collins B, Ptak R, Lang W, Scribner C, Blanchett D, Alessi T, Langecker P: Antiviral activity of CHO-SS cell-derived human omega interferon and other human interferons against HCV RNA replicons and related viruses. Antiviral Res 2007;73:118-125.

130 Li J, Li B, Zhang J, Hou L, Yu C, Fu L, Song X, Yu T, Zhang J, Ren J, Xu C, Chen W: Preparation of CHO cellderived rhIFN-omega-Fc with improved pharmacokinetics. Antiviral Res 2011;89:199-203.

131 Rohloff CM, Alessi TR, Yang B, Dahms J, Carr JP, Lautenbach SD: DUROS technology delivers peptides and proteins at consistent rate continuously for 3 to 12 months. J Diabetes Sci Technol 2008;2:461-467.

$\$ 132$ Khuroo MS, Khuroo MS: Hepatitis E: an emerging global disease - from discovery towards control and cure. J Viral Hepat 2016;23:68-79.

133 Smith DB, Simmonds P; International Committee on Taxonomy of Viruses Hepeviridae Study Group, Jameel S, Emerson SU, Harrison TJ, Meng XJ, Okamoto H, Van der Poel WH, Purdy MA: Consensus proposals for classification of the family Hepeviridae. J Gen Virol. 2014;95:2223-32.

134 Hamid SS, Atiq M, Shehzad F, Yasmeen A, Nissa T, Salam A, Siddiqui A, Jafri W: Hepatitis E virus superinfection in patients with chronic liver disease. Hepatology 2002;36:474-478.

135 Todt D, Franç ois C, Anggakusuma, Behrendt P, Engelmann M, Knegendorf L, Vieyres G, Wedemeyer H, Hartmann R, Pietschmann T, Duverlie G, Steinmann E: Antiviral Activities of Different Interferon Types and Subtypes against Hepatitis E Virus Replication. Antimicrob Agents Chemother 2016;60:2132-2139.

136 Kamar N, Izopet J, Tripon S, Bismuth M, Hillaire S, Dumortier J, Radenne S, Coilly A, Garrigue V, D’Alteroche L, Buchler M, Couzi L, Lebray P, Dharancy S, Minello A, Hourmant M, Roque-Afonso AM, Abravanel F, Pol S, Rostaing L, Mallet V: Ribavirin for chronic hepatitis E virus infection in transplant recipients. N Engl J Med 2014;370:1111-1120.

137 Peters van Ton AM, Gevers TJ, Drenth JP: Antiviral therapy in chronic hepatitis E: a systematic review. J Viral Hepat 2015;22:965-973.

138 van de Garde MDB, Pas SD, van Oord GW, Gama L, Choi Y, de Man RA, Boonstra A, Vanwolleghem T: Interferon-alpha treatment rapidly clears Hepatitis E virus infection in humanized mice. Sci Rep 2017;7:8267.

139 Kamar N, Rostaing L, Abravanel F, Garrouste C, Lhomme S, Esposito L, Basse G, Cointault O, Ribes D, Nogier MB, Alric L, Peron JM, Izopet J: Ribavirin therapy inhibits viral replication on patients with chronic hepatitis e virus infection. Gastroenterology 2010;139:1612-1618.

140 Haagsma EB, Riezebos-Brilman A, van den Berg AP, Porte RJ, Niesters HG: Treatment of chronic hepatitis E in liver transplant recipients with pegylated interferon alpha-2b. Liver Transpl 2010;16:474-477.

141 Pestka S, Krause CD, Walter MR: Interferons, interferon-like cytokines, and their receptors. Immunol Rev 2004;202:8-32.

142 Davidson S, McCabe TM, Crotta S, Gad HH, Hessel EM, Beinke S, Hartmann R, Wack A: IFNlambda is a potent anti-influenza therapeutic without the inflammatory side effects of IFNalpha treatment. Embo Mol Med 2016;8:1099-1112. 


\section{Cellular Physiology Cell Physiol Biochem 2018;51:2377-2396 \begin{tabular}{l|l|l|l|l}
\hline DOI: 10.1159/000495897 & $\begin{array}{l}\text { C) } 2018 \text { The Author(s). Published by S. Karger AG, Basel } \\
\text { www.karger.com/cpb }\end{array}$
\end{tabular}

143 Matikainen S, Pirhonen J, Miettinen M, Lehtonen A, Govenius-Vintola C, Sareneva T, Julkunen I: Influenza A and sendai viruses induce differential chemokine gene expression and transcription factor activation in human macrophages. Virology 2000;276:138-147.

144 Cella M, Facchetti F, Lanzavecchia A, Colonna M: Plasmacytoid dendritic cells activated by influenza virus and CD40L drive a potent TH1 polarization. Nat Immunol 2000;1:305-310.

145 Coccia EM, Severa M, Giacomini E, Monneron D, Remoli ME, Julkunen I, Cella M, Lande R, Uze G: Viral infection and Toll-like receptor agonists induce a differential expression of type I and lambda interferons in human plasmacytoid and monocyte-derived dendritic cells. Eur J Immunol 2004;34:796-805.

146 Thomas JM, Pos Z, Reinboth J, Wang RY, Wang E, Frank GM, Lusso P, Trinchieri G, Alter HJ, Marincola FM, Thomas E: Differential responses of plasmacytoid dendritic cells to influenza virus and distinct viral pathogens. J Virol 2014;88:10758-10766.

147 Arimori Y, Nakamura R, Yamada H, Shibata K, Maeda N, Kase T, Yoshikai Y. Type I interferon limits influenza virus-induced acute lung injury by regulation of excessive inflammation in mice. Antiviral Res 2013;99:230-237.

148 Arimori Y, Nakamura R, Yamada H, Shibata K, Maeda N, Kase T, Yoshikai Y: Type I interferon plays opposing roles in cytotoxicity and interferon-gamma production by natural killer and CD8 T cells after influenza A virus infection in mice. J Innate Immun 2014;6:456-466.

149 Matzinger SR, Carroll TD, Fritts L, McChesney MB, Miller CJ: Exogenous IFN-alpha administration reduces influenza A virus replication in the lower respiratory tract of rhesus macaques. Plos One 2011;6:e29255.

$\checkmark 150$ Kugel D, Kochs G, Obojes K, Roth J, Kobinger GP, Kobasa D, Haller O, Staeheli P, von Messling V: Intranasal administration of alpha interferon reduces seasonal influenza A virus morbidity in ferrets. J Virol 2009;83:3843-3851.

151 Strayer DR, Carter WA, Stouch BC, Stittelaar KJ, Thoolen RJ, Osterhaus AD, Mitchell WM: Protection from pulmonary tissue damage associated with infection of cynomolgus macaques by highly pathogenic avian influenza virus (H5N1) by low dose natural human IFN-alpha administered to the buccal mucosa. Antiviral Res 2014;110:175-180.

152 Jang H, Ngunjiri JM, Lee CW: Association between Interferon Response and Protective Efficacy of NS1Truncated Mutants as Influenza Vaccine Candidates in Chickens. Plos One 2016;11:e156603.

153 Osterlund P, Veckman V, Siren J, Klucher KM, Hiscott J, Matikainen S, Julkunen I: Gene expression and antiviral activity of alpha/beta interferons and interleukin-29 in virus-infected human myeloid dendritic cells. J Virol 2005;79:9608-9617.

154 Osterlund P, Pirhonen J, Ikonen N, Ronkko E, Strengell M, Makela SM, Broman M, Hamming OJ, Hartmann R, Ziegler T, Julkunen I: Pandemic H1N1 2009 influenza A virus induces weak cytokine responses in human macrophages and dendritic cells and is highly sensitive to the antiviral actions of interferons. J Virol 2010; 84:1414-1422.

155 Carolan LA, Rockman S, Borg K, Guarnaccia T, Reading P, Mosse J, Kelso A, Barr I, Laurie KL: Characterization of the Localized Immune Response in the Respiratory Tract of Ferrets following Infection with Influenza A and B Viruses. J Virol 2015;90:2838-2848.

156 Osterlund P, Strengell M, Sarin LP, Poranen MM, Fagerlund R, Melen K, Julkunen I: Incoming influenza A virus evades early host recognition, while influenza B virus induces interferon expression directly upon entry. J Virol 2012;86:11183-11193.

157 Arilahti V, Makela SM, Tynell J, Julkunen I, Osterlund P: Novel avian influenza A (H7N9) virus induces impaired interferon responses in human dendritic cells. Plos One 2014;9:e96350.

158 Xu C, Song X, Fu L, Dong D, Wu S, Li G, Yi S, Yu T, Yu R, Hou L, Chen W: Antiviral potential of exogenous human omega interferon to inhibit pandemic 2009 A (H1N1) influenza virus. Viral Immunol 2011;24:369. 374.

159 Skorvanova L, Svancarova P, Svetlikova D, Betakova T: Protective efficacy of IFN-omega AND IFN-lambdas against influenza viruses in induced A549 cells. Acta Virol 2015;59:413-417.

160 Lachova V, Skorvanova L, Svetlikova D, Turianova L, Kostrabova A, Betakova T: Comparison of transcriptional profiles of interferons, CXCL10 and RIG-1 in influenza infected A549 cells stimulated with exogenous interferons. Acta Virol 2017;61:183-190. 